\title{
Size-resolved aerosol emission factors and new particle formation/growth activity occurring in Mexico City during the MILAGRO 2006 Campaign
}

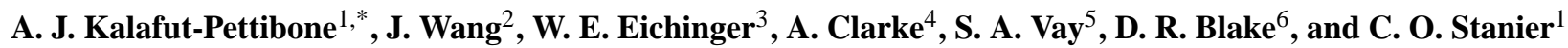 \\ ${ }^{1}$ Department of Chemical and Biochemical Engineering, University of Iowa, Iowa City, IA 52242, USA \\ ${ }^{2}$ Atmospheric Sciences Division, Brookhaven National Laboratory, Upton, NY 11973, USA \\ ${ }^{3}$ Department of Civil and Environmental Engineering, University of Iowa, Iowa City, IA 52242, USA \\ ${ }^{4}$ School of Ocean and Earth Science and Technology, University of Hawaii, Honolulu, HI 96822, USA \\ ${ }^{5}$ NASA Langley Research Center, Hampton, VA 23681, USA \\ ${ }^{6}$ Department of Chemistry, University of California-Irvine, Irvine, CA 92697, USA \\ * current address: Chemical and Biochemical Reference Data Division, Mailstop 8320 National Institute of Standards and \\ Technology, Gaithersburg, MD 20899, USA
}

Received: 31 January 2011 - Published in Atmos. Chem. Phys. Discuss.: 24 February 2011

Revised: 5 August 2011 - Accepted: 19 August 2011 - Published: 1 September 2011

\begin{abstract}
Measurements of the aerosol size distribution from $11 \mathrm{~nm}$ to 2.5 microns were made in Mexico City in March 2006, during the MILAGRO (Megacity Initiative: Local and Global Research Observations) field campaign. Observations at the urban supersite, referred to as T0, could often be characterized by morning conditions with high particle mass concentrations, low mixing heights, and highly correlated particle number and $\mathrm{CO}_{2}$ concentrations, indicative that particle number is controlled by primary emissions. Average size-resolved and total number- and volume-based emission factors for combustion sources impacting $\mathrm{T} 0$ have been determined using a comparison of peak sizes in particle number and $\mathrm{CO}_{2}$ concentration. Peaks are determined by subtracting the measured concentration from a calculated baseline concentration time series. The number emission and volume emission factors for particles from $11 \mathrm{~nm}$ to $494 \mathrm{~nm}$ are $1.56 \times 10^{15}$ particles, and $9.48 \times 10^{11}$ cubic microns per $\mathrm{kg}$ of carbon, respectively. The uncertainty of the number emission factor is approximately plus or minus $50 \%$. The mode of the number emission factor was between 25 and $32 \mathrm{~nm}$, while the mode of the volume factor was between 0.25 and 0.32 microns. These emission factors are reported as log normal model parameters and are compared with multiple emission factors from the literature. In Mexico City in the afternoon, the $\mathrm{CO}_{2}$ concentration drops during ventilation of the pol-
\end{abstract}

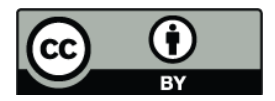

Correspondence to: C. O. Stanier (charles-stanier@uiowa.edu) luted layer, and the coupling between $\mathrm{CO}_{2}$ and particle number breaks down, especially during new particle formation events when particle number is no longer controlled by primary emissions. Using measurements of particle number and $\mathrm{CO}_{2}$ taken aboard the NASA DC-8, the determined primary emission factor was applied to the Mexico City Metropolitan Area (MCMA) plume to quantify the degree of secondary particle formation in the plume; the primary emission factor accounts for less than $50 \%$ of the total particle number and the surplus particle count is not correlated with photochemical age. Primary particle volume and number in the size range $0.1-2 \mu \mathrm{m}$ are similarly too low to explain the observed volume distribution. Contrary to the case for number, the apparent secondary volume increases with photochemical age. The size distribution of the apparent increase, with a mode at $\sim 250 \mathrm{~nm}$, is reported.

\section{Introduction}

\subsection{Motivation}

Numerous studies have shown the adverse effects of particulate matter (PM) on human health, with increased interest placed on ultrafine particles which become more toxic per unit mass with decreasing size (Mills et al., 2009; Oberdorster et al., 2005; Osornio-Vargas et al., 2003; Delfino et al., 2005). Atmospheric aerosols are known to affect the climate system by altering cloud properties, often referred to

Published by Copernicus Publications on behalf of the European Geosciences Union. 
as the indirect effect (Lohmann and Feichter, 2005). Currently, the indirect effect of aerosols on climate is highly uncertain and limits our understanding of climate sensitivity to anthropogenic perturbations (IPCC, 2007). Uncertainty of the indirect effect is in part attributed to the uncertainty in the number of cloud condensation nuclei $(\mathrm{CCN})$, or the particles on which cloud droplets form. Whether a particle will act as a CCN or not depends on the particle size, composition, and water-vapor supersaturation. Particles are introduced into the atmosphere either by direct emissions (primary particles) or homogeneous nucleation of low volatility species (secondary particles). Primary particles are introduced into the atmosphere at generally larger sizes $(10 \mathrm{~nm}$ or greater) when compared to secondary particles (Pierce and Adams, 2009). Some particles are emitted at CCN active sizes, while others must first grow in size through coagulation and condensation. Nucleated particles begin as molecular clusters, and require substantial growth to become large enough to act as CCN. The dynamic evolution of the particle size distribution involves competition between coagulation, condensation, and nucleation. Primary and secondary particles vie for growth through condensation of low volatility gas phase species, which can also homogeneously nucleate to form new particles as previously mentioned (Wang and Penner, 2009). Therefore, any uncertainty in the size distributions or rates of primary emissions or of secondary particle formation may lead to large uncertainty in the predicted $\mathrm{CCN}$ concentration (Adams and Seinfeld, 2002).

Although accurate knowledge of the size distribution and number concentration of atmospheric particles has been determined to be critical for prediction of $\mathrm{CCN}$ concentration, global models representing aerosol number concentration assume the number and size of particles from mass emissions (Chang et al., 2009; Pierce and Adams, 2007; Yu et al., 2010), due to the fact that inventories of anthropogenic emissions are based on mass rather than number concentration. While size-resolved emission factors are increasingly available, they are often determined from source-based tests or from vehicle tunnel studies. Here, we recover a size resolved number-based emission factor representative of Mexico City urban emissions. Both the emission factor itself, and the method of its recovery (particularly if refined using fast number size distribution measurements), may be valuable for continued refinement of size resolved emission factors.

\subsection{Background}

Mexico City is the largest city in North America, with a population of over 20 million people. Nearly 40 million liters of fuel are consumed each day, producing thousands of tons of pollutants (Molina et al., 2008). The city is located in the basin of the central Mexican plateau $\left(19.5^{\circ} \mathrm{N}\right)$ at an altitude of approximately $2200 \mathrm{~m}$ above sea level, with mountains to the south, west, and east. The topography and meteorology of this area reduce ventilation of pollutants, especially in the morning before the boundary layer has increased to levels where coupling with the gradient regional wind occurs, thereby contributing to the persistent air quality problems in this area (Jauregui, 1988; de Foy et al., 2006).

The air pollution in the Mexico City Metropolitan Area (MCMA) has been the topic of numerous studies. Raga and colleagues have provided an observational summary of studies conducted from 1960-2000, and concluded that the limited measurements of aerosols and their transport from major source areas was highly insufficient for understanding the evolution and environmental impacts of aerosols. This lack of information about the physical characteristics of aerosols motivated a study in 1997 by Baumgardner et al. (2000). Their measurements, taken from a mountain site in the southwest portion of the basin, concluded that a large fraction of the measured aerosols were from primary emissions based on a positive correlation with $\mathrm{CO}$. High nighttime aerosol number concentrations were suggestive of recirculation within the basin that would further impact pollutant levels. In the spring of 2003, a large scale field campaign was conducted (MCMA-2003) which contributed to the understanding and improvement of air quality in Mexico City. Dunn and colleagues (2004) conducted measurements of the aerosol size distribution from 3-48 nm in two locations in the Mexico City area; a rural site in the mountain pass in the southeast corner and another in the city's center. New particle formation events were observed on 3 of 10 days sampled. At the urban site, high concentrations of $15-25 \mathrm{~nm}$ particles correlated with high levels of $\mathrm{NO}_{\mathrm{x}}$ and $\mathrm{CO}$ and sudden decreases in condensational surface area preceded the new particle formation events (Dunn et al., 2004). Related measurements showed the significance of secondary organic and inorganic aerosol production and its contribution to particulate matter concentrations (Volkamer et al., 2006). Salcedo et al. (2006) reported that the organic mass fraction of $\mathrm{PM}_{2.5}$ as measured at the CENICA site in southeast Mexico City is on average $56 \%$, with inorganics representing $28 \%$ (Salcedo et al., 2006). The mass distribution was dominated by an internally mixed accumulation mode, and a smaller externally-mixed mode that was concluded to be related to traffic emissions (Molina et al., 2007).

Similar results were obtained during the MILAGRO (Megacity Initiative: Local and Global Research Observations) field campaign in 2006. The size distribution and composition of particles from 10 to $33 \mathrm{~nm}$ was measured northwest of the city in Tecamac by Smith and colleagues (Iida et al., 2008; Smith et al., 2008). Results from a case study of one new particle formation event suggest that the freshly nucleated particles are comprised of more organics than sulfates and that organic compounds play a dominant role in the growth of particles at this location (Smith et al., 2008). Using data collected onboard the NSF/NCAR C-130 with HR-ToF-AMS, DeCarlo and colleagues determined that organic species dominated submicron aerosol near the pollution source and in the outflow and regional air (DeCarlo et al., 
2008). Ground based measurements performed by Aiken et al. using HR-ToF-AMS also concluded that organic aerosol comprises half of the mass of fine particulate matter (Aiken et al., 2009). Source apportionment of fine organic aerosol determined that primary emissions from motor vehicles consistently account for half of the organic carbon in the urban area (Aiken et al., 2009).

The evolution of the size distribution and composition of aerosols over the Mexico City basin was measured by Kleinman and colleagues (Kleinman et al., 2008, 2009). Measurements taken aboard the DOE aircraft sampled aerosols with photochemical ages ranging from fresh emissions to day old air masses. Findings included that a 5-fold increase in aerosol volume per $\mathrm{CO}$ as a result of $0.5-1$ day of processing is due to more accumulation mode particles in aged plumes, rather than larger particles and that the increase in accumulation mode particles was due to condensational growth from Aitken mode particles, rather than volume growth (Kleinman et al., 2009).

The air quality in the basin during the MILAGRO 2006 campaign was compared to 10 years of data collected by Mexico City's automatic monitoring network (RAMA), and it was concluded that $\mathrm{PM}_{2.5}$ and $\mathrm{PM}_{10}$ levels were mostly within their usual range (de Foy et al., 2008). PM $_{10}$ maximum loadings occurred at either the end of the morning or the end of the afternoon and $\mathrm{PM}_{2.5}$ concentrations peaked around noon. The average $\mathrm{PM}_{2.5}$ and $\mathrm{PM}_{10}$ levels measured at $\mathrm{T} 0$ were $40 \mu \mathrm{g} \mathrm{m}^{-3}$ and $56 \mu \mathrm{g} \mathrm{m}^{-3}$, respectively, and were markedly impacted by traffic emissions during rush hours (Querol et al., 2008). Measurements of PM at multiple locations in parallel suggest that variability in PM levels and composition may be determined largely by atmospheric mixing and mixed layer height rather than by emission sources (Querol et al., 2008).

The quantification of particulate emissions from combustion sources is important for multiple reasons including generation of emission inventories for the development of air management and control strategies, examination of specific sources on compliance with standards, and assessment of personal and environmental exposures (Zhang and Morawska, 2002). Because many of the health and climate effects associated with atmospheric particles are influenced by size, particle emission factors should also be size resolved. Emission factors and inventories have been compiled for Mexico City; however no reports of a size resolved particle number-based emission factor exist to date.

Size-resolved emission factors can be measured in various ways. Dynamometer tests are often performed in controlled settings (Ristovski et al., 1998), but may not be representative of fleet average emissions under real world dilution and engine load conditions. On-road techniques have the advantage of sampling a wide range of vehicles with varying loads and speeds under real-world dilution conditions and can be measured from a mobile laboratory or at a stationary location (Zavala et al., 2009; Kolb et al., 2004; Jiang et al., 2005).
On-road emission factors are commonly determined using a stationary control volume, such as a roadway tunnel where emission factors can be calculated using a mass-balance approach (Jamriska and Morawska, 2001; Geller et al., 2005). This method has the advantage of providing fleet averaged emission factors over a large number of vehicles; however difficulties arise when sampling smaller particles. The reduced dilution of a control volume may change evolution of the size distribution and influence the applicability of the recovered size distribution (Kristensson et al., 2004).

An effective method for determining a fuel-based, sizeresolved, submicron particle emission factor uses the relationship between particle emissions to emission of a coemitted gaseous pollutant (Janhall and Hallquist, 2005; Jiang et al., 2005). Carbon dioxide is the primary carboncontaining product of fuel combustion and can provide an estimate of the amount of fuel burned (McGaughey et al., 2004). Relating features (i.e. peaks) in the time series of a pollutant concentration (e.g. particle number) to corresponding peaks of $\mathrm{CO}_{2}$ and $\mathrm{CO}$, allows for the emission ratio to be expressed in units of particles per mole of the gaseous compound or related to the carbon content of fuel and expressed as amount of pollutant emitted per unit of fuel consumed. Alternately, if the fleet average fuel economy is known or estimated, emission factors can be expressed per vehicle km. This method of determining fuel-based particle emission factors has previously been used in various locations (Kirchstetter et al., 1999; Westerdahl et al., 2009; Kittelson et al., 2004; Ning et al., 2008). In this study, the observed correlation between particle number and $\mathrm{CO}_{2}$ concentrations was exploited in order to determine an average size resolved number based emission factor for Mexico City. Rather than a regression of total number or a size fractionated number upon $\mathrm{CO}_{2}$ concentrations, a method was used to identify peaks of $\mathrm{CO}_{2}$, and then to determine their corresponding paired peak in particle number. The baseline (against which the peaks were determined) was calculated using a successive moving average method as described by Watson and Chow (2001). This method should be robust even in the presence of slowly varying baseline concentrations of $\mathrm{CO}_{2}$ or particle number. Key questions for this data analysis were the robustness of the method to new particle formation events, the uncertainty in the recovered emission factor, how the emission factor would compare with other vehicular emission factor studies, whether sources could be identified according to wind direction or source class, and how the recovered emission factor would compare with gas and size-resolved aerosol measurements in the megacity plume.

The technique as employed does not recover sourcespecific emission factors (e.g. on-road spark ignition, onroad diesel, coal combustion, etc.). However, it recovers the average emission factor over multiple combustion sources. 


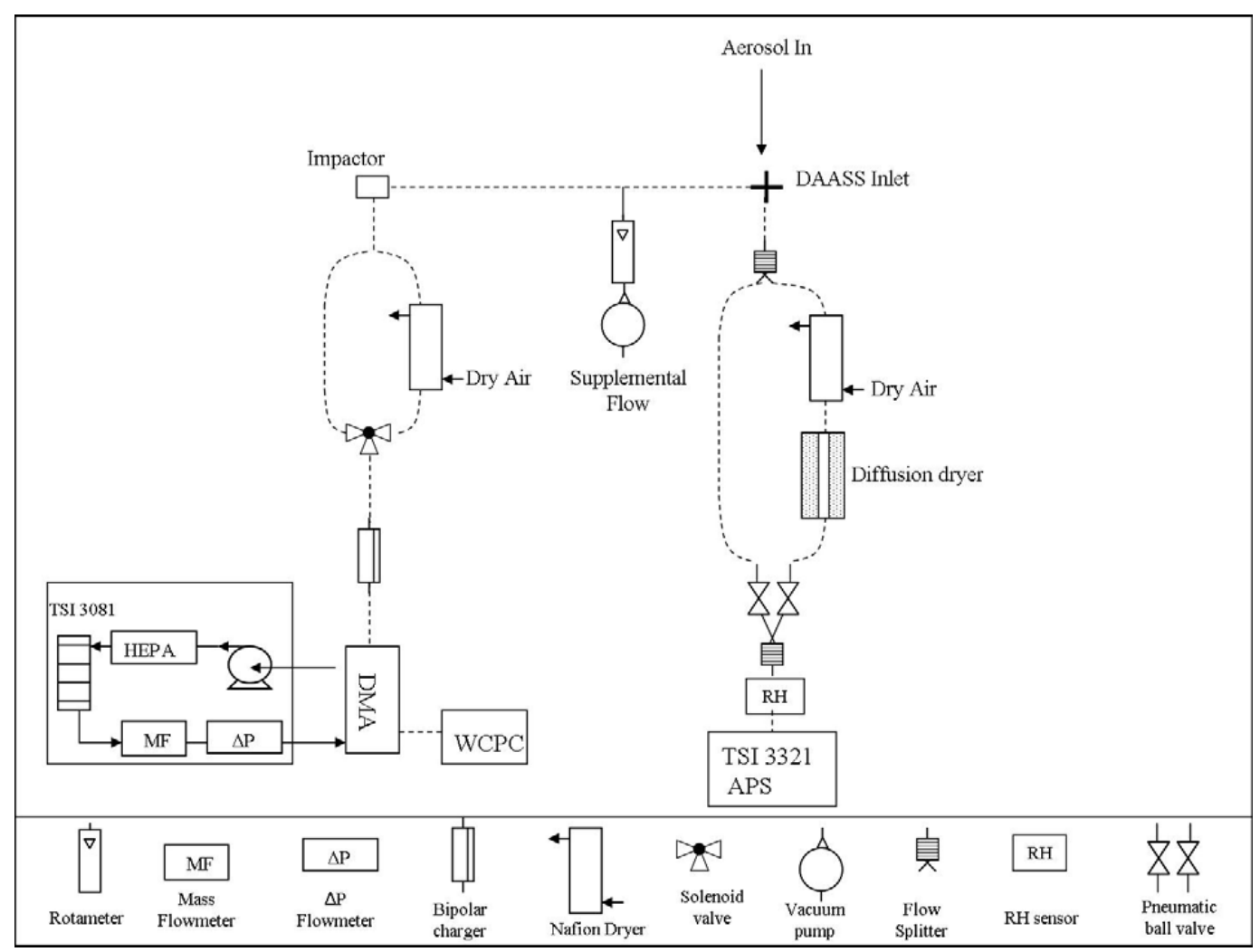

Fig. 1. University of Iowa RH-controlled inlets and sizing instrumentation.

\section{Instrumentation}

Observations were made by the University of Iowa and by the Department of Energy Brookhaven National Laboratory in Mexico City during the MILAGRO field campaign in March 2006, in order to characterize the T0 urban size distribution, to study the primary emissions around T0, and to characterize new particle formation and ultrafine particle growth. From 7 March to 29 March, measurements were taken at the T0 research location, one of the three supersites selected for the campaign. The T0 location was located inside the Instituto Mexicano del Petróleo (IMP) in the northwestern part of the basin, which is an urban background site influenced by fresh roadway traffic emissions, residential emissions and at times local industrial emissions. Instrumentation used in this work is listed in Table 1.

Two datasets of particle size distribution are used in this work. The University of Iowa operated a Scanning Mobility Particle Sizer (TSI 3081) and an Aerodynamic Particle Sizer (TSI 3321), with relative humidity controlled inlets (Stanier et al., 2004), as shown in Fig. 1. The SMPS measured the size distribution from $10.9 \mathrm{~nm}$ to $478 \mathrm{~nm}$ at $5 \mathrm{~min}$ intervals, while the APS measured the distribution from $0.542 \mu \mathrm{m}$ to $19.8 \mu \mathrm{m}$ at $20 \mathrm{~s}$ intervals. J. Wang of Brookhaven National Laboratory operated an SMPS system which measured the size distribution from 15 to $494 \mathrm{~nm}$ at $2 \mathrm{~min}$ intervals (Wang et al., 2003). The Iowa SMPS and APS switched every 5 min between a dried (typically $<20 \% \mathrm{RH}$ ) configuration and a not dried configuration. The not dried configuration was intended to sample aerosols at ambient $\mathrm{RH}$, however due to the increased temperature of the building housing the instruments relative to ambient conditions, the sample was dried before reaching the detector. The average ambient relative humidity was $43.3 \%( \pm 23.2 \%)$ and the average relative humidity in the "not dried" sample line was $19.1 \%( \pm 6.9 \%)$ In this work, the "not dried" channel is used for both the SMPS and APS analysis. The relative humidity $(\mathrm{RH})$ of the BNL SMPS sample flow was always below $30 \%$ during MILAGRO, and was below $25 \%$ for a vast majority of the size distribution measurements, suggesting sampled aerosol particles were effectively dry. The BNL SMPS was calibrated using polystyrene latex standards. Data from the BNL SMPS were reduced using the data inversion procedure described by Collins et al. (2002).

$\mathrm{CO}_{2}$ and meteorology measurements were made using a Licor LI-7500 $\mathrm{CO}_{2}$ analyzer, which measured ambient $\mathrm{CO}_{2}$ concentrations from an open field in the middle of the IMP, approximately $150 \mathrm{~m}$ away. The location of the $\mathrm{CO}_{2}$ monitor with respect to the particle sizing equipment is shown in Fig. 2. 
Table 1. Measurements used in the data analysis for this work.

\begin{tabular}{|c|c|c|c|}
\hline Instrument & Group (PI) & Measurement & $\begin{array}{l}\text { Temporal } \\
\text { resolution }\end{array}$ \\
\hline $\begin{array}{l}\text { Aerodynamic Particle Sizer } \\
\text { (TSI Inc., 3321) }\end{array}$ & $\begin{array}{l}\text { University of Iowa } \\
\text { (C. Stanier) }\end{array}$ & $\begin{array}{l}\text { Size distribution from } \\
0.542 \mu \mathrm{m} \text { to } 19.8 \mu \mathrm{m}\end{array}$ & $20 \mathrm{~s}$ \\
\hline SMPS (TSI Inc., 3081) & $\begin{array}{l}\text { University of Iowa } \\
\text { (C. Stanier) }\end{array}$ & $\begin{array}{l}\text { Size distribution from } \\
10.9 \mathrm{~nm} \text { to } 478 \mathrm{~nm}\end{array}$ & $5 \mathrm{~min}$ \\
\hline SMPS (TSI Inc., 3081) & $\begin{array}{l}\text { Brookhaven National Lab } \\
\text { (J. Wang) }\end{array}$ & $\begin{array}{l}\text { Size distribution from } \\
15 \mathrm{~nm} \text { to } 494 \mathrm{~nm}\end{array}$ & $2 \mathrm{~min}$ \\
\hline LI-COR LI-7500 & $\begin{array}{l}\text { University of Iowa } \\
\text { (W. Eichinger) }\end{array}$ & $\mathrm{CO}_{2}$ & $1 \mathrm{~s}$ \\
\hline $\begin{array}{l}\text { Integrating Nephelometer } \\
\text { (TSI Inc., 3563) }\end{array}$ & $\begin{array}{l}\text { Department of Energy } \\
\text { (N. Marley) }\end{array}$ & $\begin{array}{l}\text { Aerosol scattering at } 450 \text {, } \\
550 \text {, and } 700 \mathrm{~nm}\end{array}$ & \\
\hline Vaisala WXT510 & $\begin{array}{l}\text { Department of Energy } \\
\text { (N. Marley) }\end{array}$ & Wind speed and direction & $1 \min 40 \mathrm{~s}$ \\
\hline $\begin{array}{l}\text { Thermo Andersen } \mathrm{PM}_{2.5} \text { Beta } \\
\text { Attenuation Monitor (CAM, } \\
\text { SJA), } \\
\text { TEOM 1400a-FDMS } 8500 \\
\mathrm{PM}_{2.5} \text { (MER) }\end{array}$ & $\begin{array}{l}\text { Mexico City Ambient } \\
\text { Air Monitoring Network } \\
\text { (RAMA) }\end{array}$ & $\mathrm{PM}_{2.5}$ & Hourly \\
\hline $\begin{array}{l}\text { Modified LI-COR } 6252 \text { ana- } \\
\text { lyzer }\end{array}$ & NASA (S. Vay) & $\mathrm{CO}_{2}$ (DC-8 aircraft) & $1 \mathrm{~s}$ \\
\hline Modified DMA & NASA (A. Clarke) & $\begin{array}{l}\text { Particle number } \\
\text { (DC-8 aircraft) }\end{array}$ & \\
\hline $\begin{array}{l}\text { Canister samples of trace } \\
\text { gases }\end{array}$ & UC Irvine (D. Blake) & $\begin{array}{l}\text { Benzene, Toluene (DC- } 8 \text { air- } \\
\text { craft) }\end{array}$ & $\begin{array}{l}1-2 \min \\
4-5 \text { min }\end{array}$ \\
\hline
\end{tabular}

For evaluation of the particle number and particle volume time series, comparisons to nephelometer measurements of light scattering at $700 \mathrm{~nm}$ (Marley et al., 2009) was used. Comparisons to hourly $\mathrm{PM}_{2.5}$ readings from the Mexico City ambient air monitoring network were also used (RAMA, Red Automatica de Monitoreo Atmosferico).

The measurement of wind speed and wind direction used in this analysis was obtained by the Department of Energy (N. Marley) at the T0 location using a Vaisala WXT 510 weather transmitter.

In order to apply the emission factor to the MCMA plume downwind of the city, measurements of aerosol size distribution and $\mathrm{CO}_{2}$ obtained via aircraft were required. The measurements of the aerosol size distribution used in this work were obtained onboard the NASA DC- 8 aircraft by the University of Hawaii group HiGEAR using a modified long differential mobility analyzer $(10 \mathrm{~nm}-400 \mathrm{~nm})$ (Roberts et al., 2010). Sampling was conducted through an NCAR solid diffuser inlet under dry instrument conditions (less than $30 \%$ $\mathrm{RH})$. A modified LI-COR (6252) non-dispersive infrared gas analyzer was used to determine the $\mathrm{CO}_{2}$ mixing ratios and was operated under constant pressure (Vay et al., 2003). Measurements of benzene and toluene, used here to approximate plume age, were obtained using whole air samples collected by D. Blake (UC Irvine). Samples were collected in stainless steel canisters and analyzed at the UC Irvine laboratory within 7 days of collection (Baker et al., 2008).

\section{Data analysis techniques}

The Iowa SMPS number size distribution data used in this work were corrected for inlet losses, which occurred due to the tubing and valves required for the alternating drying of the sample (e.g. $32 \%$ transmission was estimated at $15 \mathrm{~nm}$, and $93 \%$ transmission at $102 \mathrm{~nm}$ ). The BNL SMPS was designed to measure the size distribution and concentration of aerosols at T0 without additional processing and therefore had a shorter inlet, less upstream valves and fittings, and a higher efficiency. The BNL inlet efficiency was calculated using the flow rates and tubing lengths of the sampling line as described in Wang et al. (2002) and applied to correct 


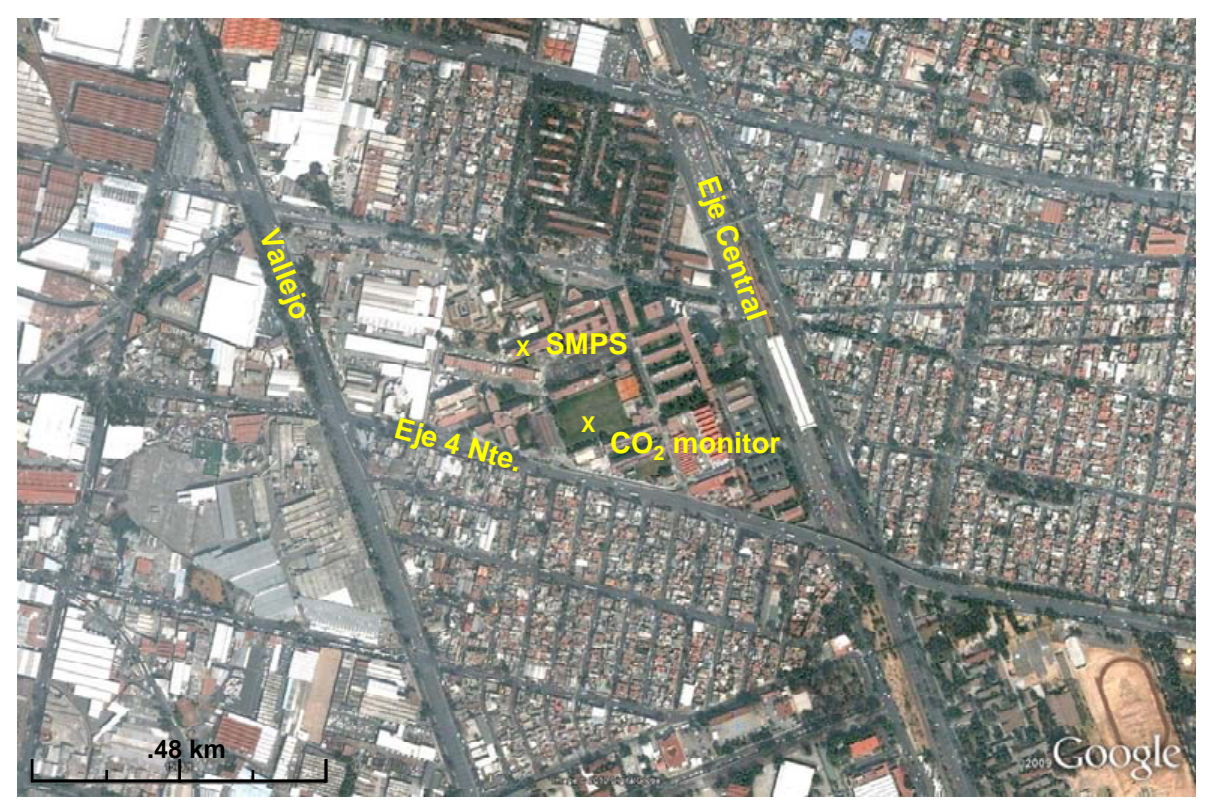

Fig. 2. Aerial view of the T0 research site and surrounding land use. The locations of the $\mathrm{CO}_{2}$ monitor and SMPS instrumentation are denoted by an "x".

the SMPS data set. Then the transmission efficiencies for the Iowa SMPS were calculated to maximize hourly average agreement with the BNL SMPS. These are similar to transmission efficiencies measured using a reconstructed inlet after the study (Kalafut-Pettibone, 2009).

The APS data was corrected for inlet transmission efficiency which ranged from $93 \%$ transmission at $500 \mathrm{~nm}$ to $33 \%$ transmission at 2.5 microns. To enable comparability between the APS and SMPS size distribution, the APS data (originally calibrated for aerodynamic diameter) was shifted to the smaller equivalent electrical mobility diameters using the approach of Khlystov et al. (2004). This requires an assumed density $\left(1.43 \mathrm{~g} \mathrm{~cm}^{-3}\right.$ was used based on the Mexico City density and composition as determined by DeCarlo et al., 2008) and an assumption of spherical particles. After application of these transmission efficiencies and the density shift, two important mismatches in our Mexico City data were notable when doing instrument-to-instrument validation checks. The first mismatch was between the SMPS and the APS, with the ratio between the distributions as 0.35 (APS/SMPS) at $480 \mathrm{~nm}$ (corresponds to $574 \mathrm{~nm}$ aerodynamic diameter). The second mismatch was that the total reconstructed mass [(SMPS volume + APS volume) times density] was lower than it would need to be for comparison with nearby $\mathrm{PM}_{2.5}$ continuous mass measurements.

In light of this limited agreement at $480 \mathrm{~nm}$ mobility diameter, and lacking more size-specific data on the APS measurement accuracy, two alternate final APS time series (e.g. size distributions) were calculated. We denote a time series created using a size independent correction (i.e. multiplying by $0.35^{-1}$ or 2.86 to all sizes) as the "base" case. An alter- nate, less aggressive correction was made using size dependent counting efficiencies measured for submicron particles (Leinert and Wiedensohler, 2000). The values are of $58 \%$ at 0.51 microns (aerodynamic diameter) to $90 \%$ at 1 micron; the alternate treatment has no additional corrections to particle counts above 1.5 microns beyond the original transmission efficiencies.

The mismatch between APS and SMPS may be related to two difficult issues that arise when using an APS in comparison with mass and electrical mobility, especially in environments with a large fraction of combustion particles. There is a known counting efficiency bias in the APS at sizes less than about 1.3 microns and this is not accounted for in the alternate data reduction. The effective density of $1.43 \mathrm{~g} \mathrm{~cm}^{-3}$ used in this work reflects the bulk density of the aerosol components (combined in a mass weighted average according to AMS measured mass), which may not be equal to the effective density of the particles needed for the conversion between mobility and electrical mobility. Studies have shown size-dependent effective densities, effective densities of less than unity in combustion environments, and increases in effective density as the result of photochemical aging (Geller et al., 2006). A size and temporally varying effective density could explain the scatter that we observed in the SMPS-APS overlap when a fixed effective density was assumed. The APS-SMPS mismatch did have a diurnal pattern (APS/SMPS at $480 \mathrm{~nm}$ at a minimum from 10:00 p.m.-09:00 a.m. and at a maximum from noon-04:00 p.m.). Such a pattern is consistent with effective densities of $<1$ from combustion and increases due to photochemical processing. While this is suggestive that a time-varying correction is needed, additional 


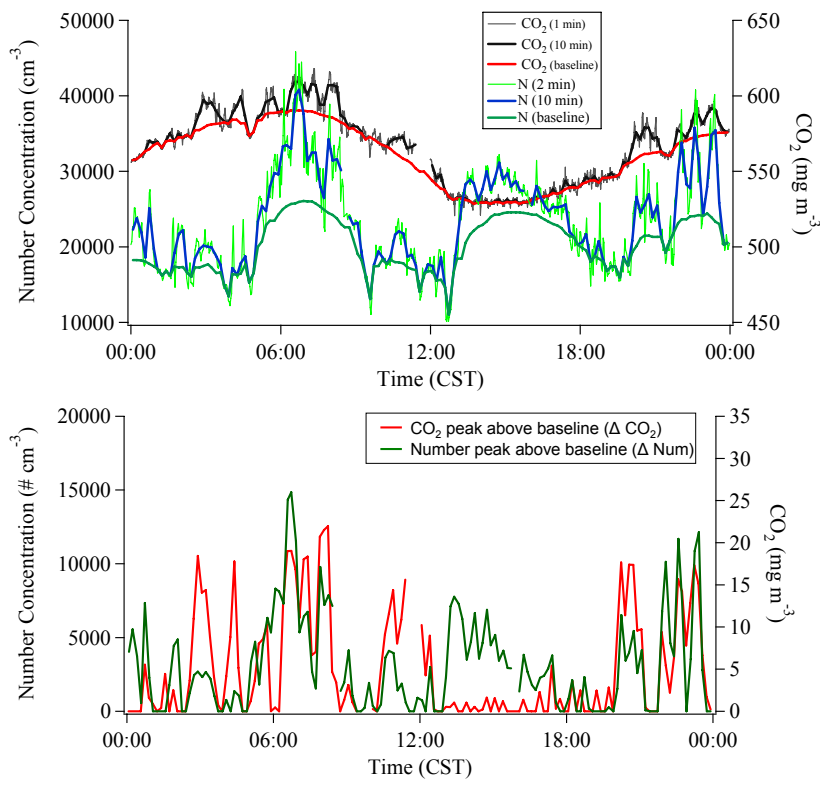

Fig. 3. Time series data for 17 March, illustrating the method used to retrieve the number-based emission factors based on the correlation between $\mathrm{CO}_{2}$ and particle number for Mexico City.

information such as collocated impactor measurements, measured shape factors, or mass mobility distributions would be necessary to apply this to the field study data.

The ratio of the alternate to base counts and emission factors are discussed in the results and discussion section. The alternate treatment decreased recovered total aerosol volume by about $5 \mu \mathrm{m}^{3} \mathrm{~cm}^{-3}$, decreased the correlation between nephelometer extinction and SMPS + APS volume $\left(R^{2}\right.$ for alternate processing was lower than $R^{2}$ for base), and did not match as well as the base case for comparison of the reconstructed mass with the RAMA network values. However, the difference between the base and alternate assumptions partially quantify APS measurement uncertainty.

The decision to jointly analyze the $\mathrm{CO}_{2}$ and number time series was based on an initial inspection of the dataset, where a Pearson correlation coefficient of 0.6 was noted between fine particles and $\mathrm{CO}_{2}$; however, periods with much higher correlation existed. The early morning hours had the highest correlation, with $4 \mathrm{~h}$ correlations from 04:00-08:00 a.m. reaching 0.93 on some days. Figure 4 illustrates the correlation coefficient between particle number and $\mathrm{CO}_{2}$ as a function of the time of day (a) and also includes a scatterplot of number vs. $\mathrm{CO}_{2}$ for the entire measurement period (b). Figure $4 \mathrm{c}$ presents size resolved diurnal correlation coefficients. These are relatively high for all sizes and times of day except for ultrafine particles in the afternoon and super micron particles in the early evening. The high correlation during the midday is due to simultaneously decreasing $\mathrm{CO}_{2}$ and particle concentrations at sizes greater than about $70 \mathrm{~nm}$. The blue colors show an anticorrelation between ultrafine parti-
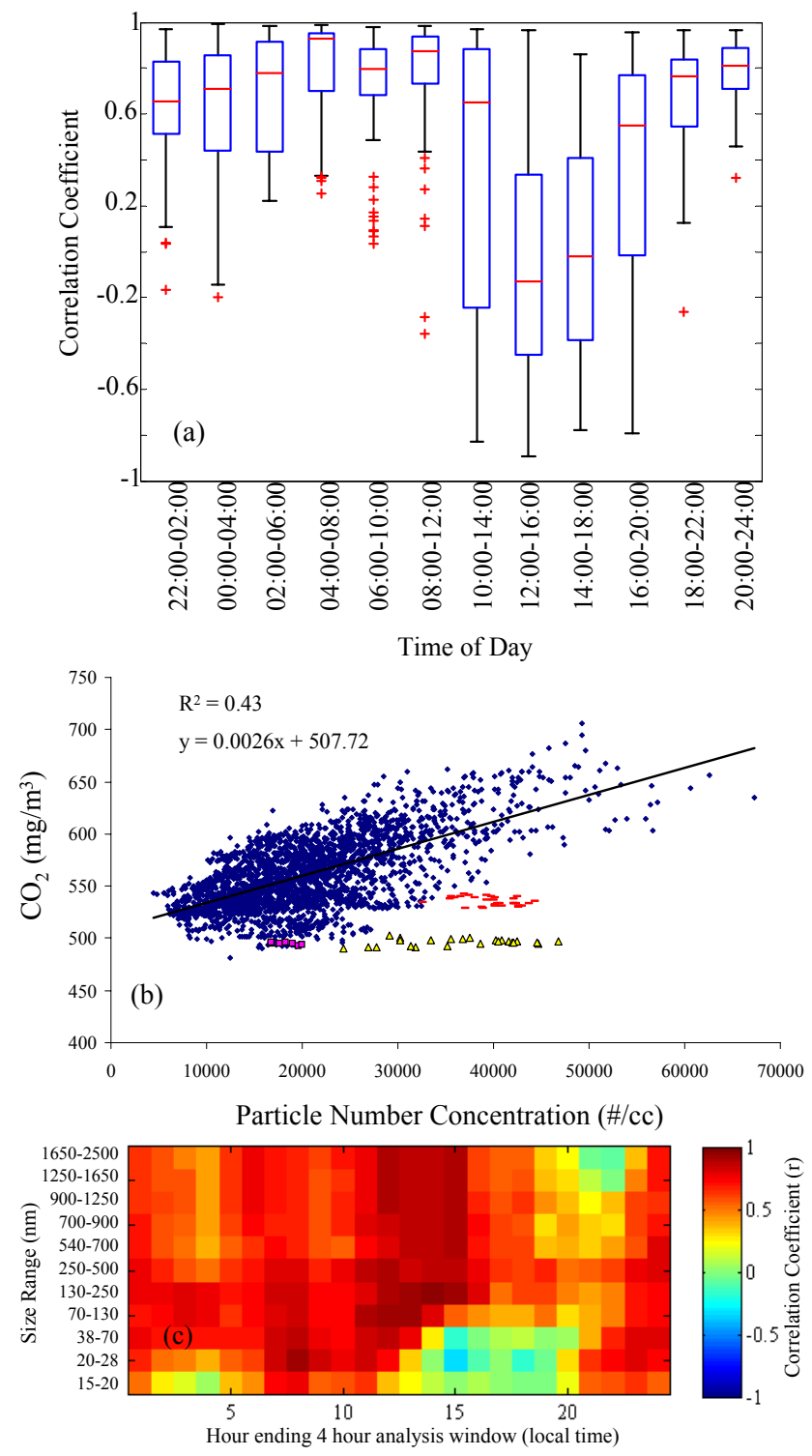

Fig. 4. (a) Correlation coefficient of 10-min averaged $\mathrm{CO}_{2}$ and total number over 4-h periods, (b) 10-min averages of $\mathrm{CO}_{2}$ concentration versus particle number concentration for the entire period from 9 March to 29 March (squares, triangles and dashed lines highlight measurements obtained during new particle formation events) and (c) correlation coefficient for various size ranges. Local time ( $\mathrm{x}$ axis) is the last hour of a 4-h time window over which correlation with $\mathrm{CO}_{2}$ is analyzed (e.g. hour 15 shows correlations from 11:00 until 15:00).

cles and $\mathrm{CO}_{2}$ in the afternoon. Although the biosphere respiration contribution to the $\mathrm{CO}_{2}$ concentration would also be at a maximum during the early morning, the biogenic sources of $\mathrm{CO}_{2}$ were determined to be insignificant (emissions were dominated by anthropogenic activity) according to flux measurements of $\mathrm{CO}_{2}$ obtained during the campaign (Velasco et al., 2009). 
The calculation of the number-based emission factor was not done directly from the raw concentrations, but required an additional data reduction step where the number and $\mathrm{CO}_{2}$ concentration time series were separated into a baseline component and a "peak" component above baseline. This was done at $10 \mathrm{~min}$ time resolution. The technique is an adaptation of previous emission factor calculations by Jiang et al. (2005) and utilized a simple peak identification and quantification scheme used by Watson and Chow (2001). In Jiang et al. (2005), a mobile laboratory with fast (1-s) $\mathrm{CO}_{2}$ data, used the 5th lowest $1 \mathrm{~s}$ reading in a $3 \mathrm{~min}(180 \mathrm{~s})$ window as the on-road background level. $\mathrm{CO}_{2}$ peaks were then calculated by subtracting this background. Similar background subtraction was performed for all compounds of interest. $\mathrm{CO}_{2}$ datapoints $42 \mathrm{ppm}$ above background were included in a database of "peaks" and the ratios of pollutants (above their background concentrations) to the $\mathrm{CO}_{2}$ peaks was compiled, and then averaged to determine the mean emission factor for each species in question.

As opposed to Jiang et al. where 1-10 s data were available for all species, and all measurements were collocated, in this study there were relatively slow measurements (e.g. 2 min for the BNL SMPS, and $5 \mathrm{~min}$ for the Iowa SMPS), and there was a separation distance of $150 \mathrm{~m}$ between the $\mathrm{CO}_{2}$ measurement and the particle measurement. This required the adoption of an analysis using longer temporal averaging.

For isolation of number and $\mathrm{CO}_{2}$ peaks to compare in this study, peaks were isolated relative to a baseline concentration calculated by the successive moving average technique of Watson and Chow (2001). Illustrated for a $24 \mathrm{~h}$ period in Fig. 3, the result of this technique is a 10 min time series of baseline and peak concentrations. Figure 3a shows 1-min $\mathrm{CO}_{2}$ and 2-min number concentrations, the 10-min averages of both signals, and the baseline concentrations of each. Figure $3 \mathrm{~b}$ shows the peaks above the baseline concentration for both signals (which will be denoted as $\Delta \mathrm{CO}_{2}$ and $\Delta \mathrm{Num}$ ) which are used to calculate the emission factor. The baseline and peak values were constructed as follows. Concentrations were averaged to a $10 \mathrm{~min}$ time basis. This put all the measurements on a common time basis regardless of their native time resolution, which ranged from $0.1 \mathrm{~s}\left(\mathrm{CO}_{2}\right.$ concentration) to $5 \mathrm{~min}$ (University of Iowa SMPS). 6-h average concentrations were compared to the $10 \mathrm{~min}$ averaged data, and the lower of each pair was retained in a tentative baseline time series. Then the tentative baseline was smoothed using a 3-h averaging time, and the resulting values were compared to the original $10 \mathrm{~min}$ time series, with retention of the lower values in the tentative baseline. A third round of averaging ( $1 \mathrm{~h}$ averaging time) and comparison was done to yield a final baseline time series which represents the regional background concentration plus the urban background. Watson and Chow (2001) approximate influence distances for short duration peaks using Pasquill Gifford curves (plot of distance from source versus plume dimension). The estimated horizontal plume dimensions are $70-1000 \mathrm{~m}$ at $2 \mathrm{~km}$ away from a continuous source. Plumes of these dimensions could cause short duration $(<10 \mathrm{~min})$ responses in the samplers. In other words, the baseline represents a regional background plus a well mixed urban background originating from distances likely farther than $0.2-2 \mathrm{~km}$ away. Peaks are caused by smaller plumes that can traverse the sampling site in $<10 \mathrm{~min}$, which are likely from sources closer than $2 \mathrm{~km}$.

The 50th percentile of the $\mathrm{CO}_{2}$ peak population was $1.6 \mathrm{mg} \mathrm{m}^{-3}$ and the 95 th percentile peak size was $25 \mathrm{mg} \mathrm{m}^{-3}$. To calculate emission factors, all $\mathrm{CO}_{2}$ peaks above a threshold were selected, and the number $/ \mathrm{CO}_{2}$ ratio of each of these $10 \mathrm{~min}$ periods is calculated. A threshold of $6 \mathrm{mg} \mathrm{m}^{-3}$ of $\mathrm{CO}_{2}$ was used and sensitivity to this threshold is discussed. The technique is applied to total number and also to the number concentration in specific diameter bins to give a size-resolved emission factor.

Emission factors determined at $\mathrm{T} 0$ are based on the ratio of the change in particle concentration to the change in mass concentration of $\mathrm{CO}_{2}$, e.g. "particle number $\mathrm{cm}^{-3}\left(\mathrm{mg} \mathrm{CO}_{2}\right.$ $\left.\mathrm{m}^{-3}\right)^{-1}$ ". Both concentrations are on an actual volume basis (not corrected to a standard pressure and temperature or for water vapor). This can be easily converted to "particle number $(\mathrm{kg} \mathrm{C})^{-1}$ ", which is invariant to changes in pressure, temperature, and water mixing ratio. Conversion to other ratio based metrics, such as "particle number $\mathrm{cm}^{-3}$ ( $\mu$ mole $\mathrm{CO}_{2}$ per mol) $)^{-1}$ " require specification of the relevant temperature and pressure, and whether the $\mathrm{CO}_{2}$ concentration is on a dry or wet basis. The equation used to convert the measured emission factors between various pressure, temperature, and water vapor combinations is:

$$
\begin{aligned}
& C_{n, \text { predict }} \mid T, P, P_{\mathrm{H} 2 \mathrm{O}}= \\
& \quad\left[C_{n \text {, measure }} / C_{\mathrm{CO} 2, \text { measure }}\right] 1.807 \frac{\left(P-P_{\mathrm{H} 2 \mathrm{O}}\right)}{1 \text { bar }} \frac{293 \mathrm{~K}}{T}\left[\chi_{\mathrm{CO} 2}\right]
\end{aligned}
$$

where $C_{n \text {,predict }}$ is the expected primary particle concentration in $\mathrm{cm}^{-3}$ at the specified temperature $(T$ in $\mathrm{K})$, total pressure $(P$ in bar $)$, and water partial pressure $\left(P_{\mathrm{H} 2 \mathrm{O}}\right.$ in bar). $C_{n \text {,measure }} / \mathrm{C}_{\mathrm{CO} \text {, measure is the original measured emis- }}$ sion factor (in the current work in particle number $\mathrm{cm}^{-3}$ and $\mathrm{mg} \mathrm{CO}_{2} \mathrm{~m}^{-3}$, respectively, at local conditions). $\chi_{\mathrm{CO} 2}$ is the $\mathrm{CO}_{2}$ mixing ratio in $\mu$ mole per mole dry air. 1.807 is a conversion factor specific to the selected units.

\section{Results and discussion}

\subsection{Summary statistics of dataset}

For the common period (shared among the ground-based instruments) of 10 March to 25 March, the mean values and distributions of the key experimental variables are given in Table 2. The mean number concentration (as measured by SMPS) in the $15-494 \mathrm{~nm}$ size range was $2.1 \times 10^{4} \mathrm{~cm}^{-3}$. The mean $\mathrm{CO}_{2}$ concentration measured at $\mathrm{T} 0$ was $559 \mathrm{mg} \mathrm{m}^{-3}$ $\left(392 \mu\right.$ moles mol$\left.^{-1}\right)$. The conversion from $\mathrm{CO}_{2}$ mixing ratio 

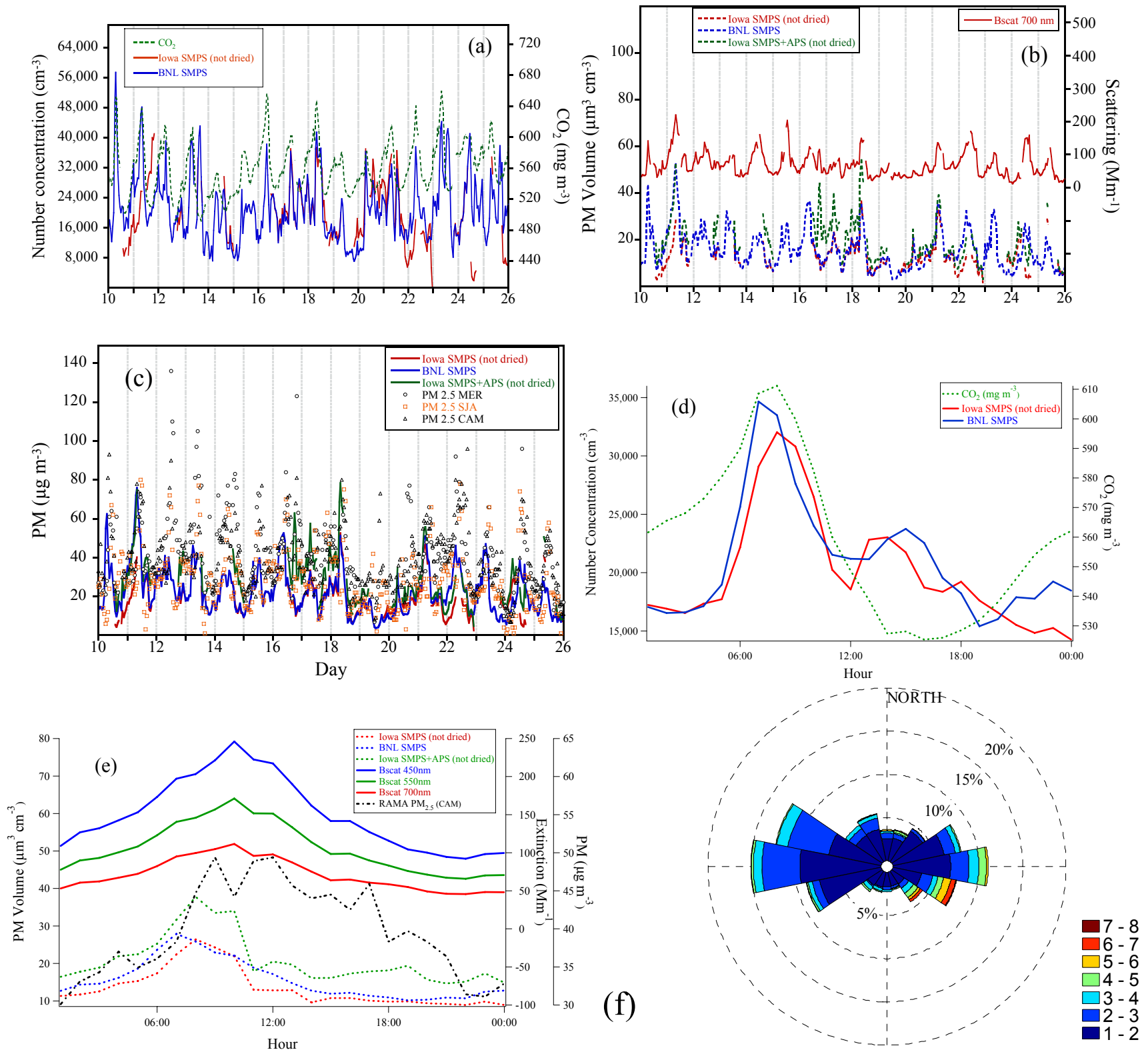

Fig. 5. Time series measurements made at the $\mathrm{T} 0$ research site during March 2006. (a) Particle number concentration ( $\mathrm{SMPS}$ ) and $\mathrm{CO}_{2}$, (b) particle volume (SMPS and APS) and total aerosol scattering (nephelometer), (c) estimated PM $_{2.5}$ (SMPS and APS) and nearby (within $10 \mathrm{~km}$ ) $\mathrm{PM}_{2.5}$ measurements from 3 different RAMA monitoring locations, (d) diurnal average for $\mathrm{CO}_{2}$ and particle number concentration, (e) diurnal average for particle volume (SMPS, APS), extinction (nephelometer), and PM mass (RAMA), (f) grand average wind rose for wind speed and direction at T0, in meters per second.

to mass concentration was done continuously using simultaneous measurement of pressure and temperature as measured adjacent to the $\mathrm{CO}_{2}$ monitor.

The time series of several of the key measurements in this work are shown in Fig. 5. Because of the uncertainty in the APS inlet transmission, several comparisons were made between metrics sensitive to aerosol volume and mass. Available at $\mathrm{T} 0$ was a 3-wavelength nephelometer, and the nearby (within $10 \mathrm{~km}$ ) hourly $\mathrm{PM}_{2.5}$ monitoring sites, operated by the RAMA network. Figure 5a represents the time series of number and $\mathrm{CO}_{2}$ concentration for the period from $10 \mathrm{March}$ to 25 March and illustrates the correlation between the two signals. Figure $5 \mathrm{~b}$ provides a time series of particulate matter (PM) volume and aerosol scattering at $700 \mathrm{~nm}$ as measured by the nephelometer for the same time period. PM volume was then converted to PM mass using the assumed density of $1.43 \mathrm{~g} \mathrm{~cm}^{-3}$ as previously discussed and for comparison with local $\mathrm{PM}_{2.5}$ measurements (Fig. 5c). The correlation 
Table 2. Mean values and distributions of ground-based measurements at T0 from 10 March to 25 March 2006.

\begin{tabular}{lccc}
\hline Measurement & Mean & Maximum & Minimum \\
\hline $\mathrm{CO}_{2}$ & $559 \mathrm{mg} \mathrm{m}^{-3}$ & $659 \mathrm{mg} \mathrm{m}^{-3}$ & $492 \mathrm{mg} \mathrm{m}^{-3}$ \\
& $392 \mu \mathrm{mol} \mathrm{mol}^{-1}$ & $454 \mu \mathrm{mol} \mathrm{mol}^{-1}$ & $359 \mu \mathrm{mol} \mathrm{mol}^{-1}$ \\
Particle number (BNL) & $2.1 \times 10^{4} \mathrm{~cm}^{-3}$ & $5.7 \times 10^{4} \mathrm{~cm}^{-3}$ & $7.1 \times 10^{3} \mathrm{~cm}^{-3}$ \\
Particle number (Iowa, not dried) & $1.9 \times 10^{4} \mathrm{~cm}^{-3}$ & $4.1 \times 10^{4} \mathrm{~cm}^{-3}$ & $1.9 \times 10^{3} \mathrm{~cm}^{-3}$ \\
Temperature & $17.6^{\circ} \mathrm{C}$ & $29.4{ }^{\circ} \mathrm{C}$ & $8.8^{\circ} \mathrm{C}$ \\
Relative humidity & $39.4 \%$ & $86.6 \%$ & $6.3 \%$ \\
\hline
\end{tabular}

Table 3. Summary of new particle formation events during the MILAGRO field campaign. The average wind dir represents the wind direction averaged over the $10 \mathrm{~min}$ preceding the event and the $10 \mathrm{~min}$ after the onset of the event.

\begin{tabular}{cccc}
\hline Date & $\begin{array}{c}\text { Start time } \\
(\mathrm{CST})\end{array}$ & $\begin{array}{c}\text { Growth rate } \\
\left(\mathrm{nm} \mathrm{h}^{-1}\right)\end{array}$ & $\begin{array}{c}\text { Average wind } \\
\text { dir. (degrees) }\end{array}$ \\
\hline 16 March & $10: 30,12: 50$ & $16.5,4.9$ & 219,103 \\
17 March & $12: 50$ & 5.9 & 38 \\
21 March & $11: 30$ & 11.1 & 253 \\
23 March & $10: 30$ & 10.6 & 259 \\
24 March & $10: 30$ & 17.7 & 291 \\
25 March & $13: 45$ & 7.8 & 317 \\
\hline
\end{tabular}

coefficient $(r)$ of PM mass and aerosol scattering (nephelometer, $550 \mathrm{~nm}$ ) was determined to be 0.84 (not shown). The slope of the regression line, which represents the scattering per unit mass, is $4.1 \mathrm{~m}^{2} \mathrm{~g}^{-1}$ which is in the range of expected values for urban pollution (Bates et al., 2006). Diurnal averages are provided in Fig. 5d and e. Aerosol number and $\mathrm{CO}_{2}$ reached peak concentrations at 07:00-08:00 a.m. (all times Central Standard Time, which is UTC $-6 \mathrm{~h}$ ). $\mathrm{CO}_{2}$ and particle number drop together due to boundary layer ventilation from 09:00-11:00 a.m., and then $\mathrm{CO}_{2}$ continues to drop to a minimum at 04:00 p.m., while particle number (on average) increases during the afternoon, due to higher numbers at sizes below $\sim 30 \mathrm{~nm}$. Aerosol volume peaks from 08:0010:00 a.m., while extinction peaks at 10:00 a.m. as well. The wind rose representing wind speed and direction for the period from March 10 to 25 March (Fig. 5f) shows winds predominantly from the west and east, with the high wind velocity periods from the east south east.

In order to further evaluate the APS data, a comparison with the $700 \mathrm{~nm}$ nephelometer data was conducted. The total aerosol volume as determined by the SMPS and APS was considered together with light scattering at $700 \mathrm{~nm}$, for all days with over $6 \mathrm{~h}$ of data (11 days total). Hours during new particle formation were excluded. The average correlation $\left(R^{2}\right)$ for the 11 days examined is 0.87 . The same calculation was then repeated using only SMPS volume, rather than SMPS+APS volume and the correlation $\left(R^{2}\right)$ decreased to 0.74 .

\subsection{Ultrafine particle growth events}

Conditions at T0 could often be characterized by highly correlated particle number and carbon dioxide concentrations, indicative that particle number is controlled by primary emissions. During new particle formation events, particle number is no longer controlled by primary emissions and the correlation between particle number and $\mathrm{CO}_{2}$ breaks down. This can be observed in the 17 March time series of number concentration and $\mathrm{CO}_{2}$ shown in Fig. 3b, where peaks above baseline of $\mathrm{CO}_{2}$ and number $\left(\Delta \mathrm{CO}_{2}\right.$ and $\left.\Delta \mathrm{Num}\right)$ are correlated until the onset of the event shortly after 12:00 CST at which point number concentration increases and $\mathrm{CO}_{2}$ levels decrease.

Ultrafine particle growth events, which were qualitatively identified by prominent and growing modes in the size range $10-15 \mathrm{~nm}$, were observed on 6 of $16(37.5 \%)$ days sampled at the T0 location. Events typically began between 10:30 and 13:00 local time. The growth rates of the ultrafine particles varied between 4.9 and $17.7 \mathrm{~nm} \mathrm{~h}^{-1}$, which are somewhat higher than the average reported range for other urban areas $\left(0.5-9 \mathrm{~nm} \mathrm{~h}^{-1}\right)$ (Kulmala et al., 2004). Table 3 provides a summary of the events and Fig. 6 shows the size-distribution from $15-500 \mathrm{~nm}$ for the 6 days where new particle formation occurred.

One commonality among all particle formation and growth events is lower than average particle number concentration just prior to the onset of the event. Favorable conditions for new particle formation often include low preexisting aerosol surface area, which acts as a sink for condensable vapors (Kulmala and Kerminen, 2008), and therefore this result is consistent with previous observations of new particle formation in Mexico City (Dunn et al., 2004) and various other locations (Clarke, 1993; Weber et al., 1997; Kulmala et al., 2004). It is known that the Mexico City basin experiences substantial ventilation during the afternoon (de Foy et al., 2006, 2009; Banta, 1985) which likely provides an explanation for rapid decreases in condensational surface area. Five of six of the particle formation/growth events 


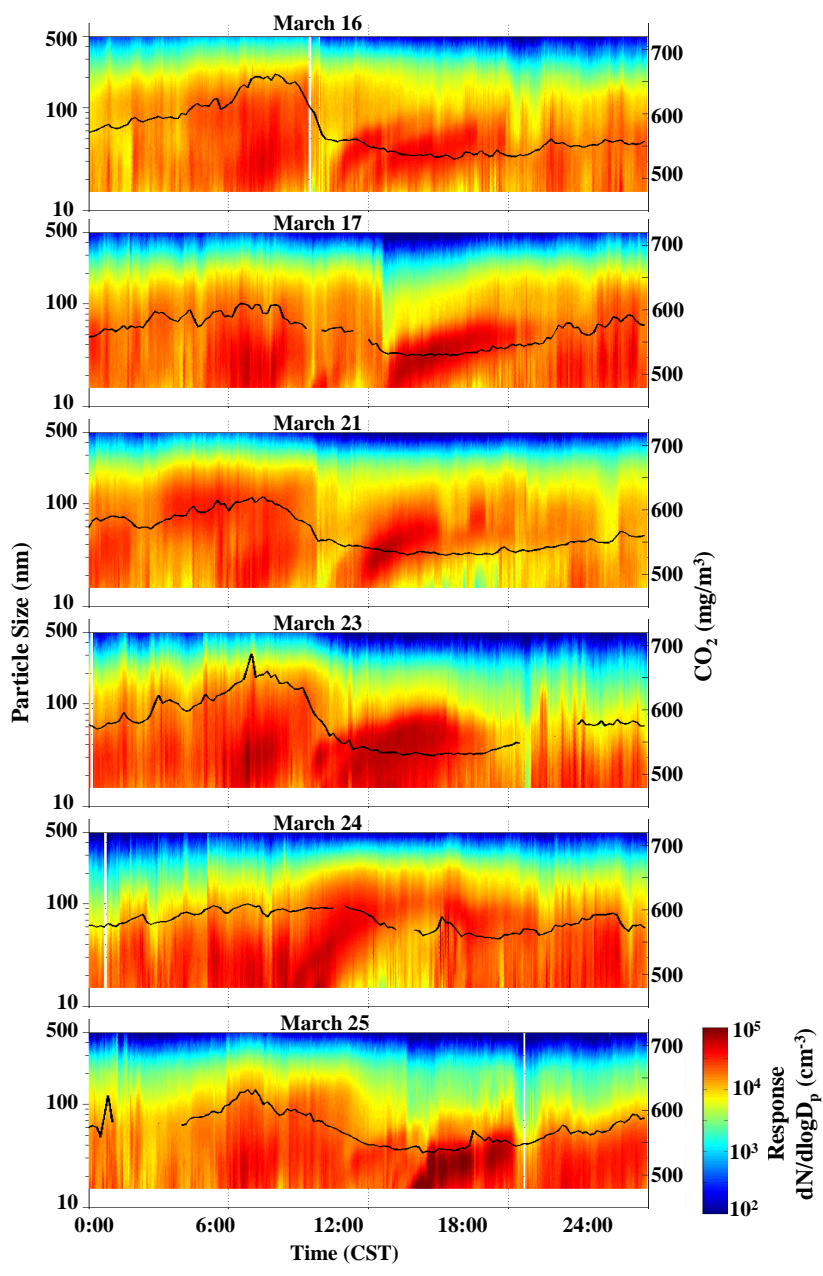

Fig. 6. Colorplots of ultrafine growth events. Black lines show $\mathrm{CO}_{2}$ concentrations.

sampled in this study have decreases in $\mathrm{CO}_{2}$ and aerosol scattering leading to an increase in number concentration, consistent with previous observations.

\subsection{Recovered emission factor}

The recovery of the primary emission factor was done twice - once with all available study hours, and once restricting the dataset to the hours of 04:00-10:00 a.m. local time, the time period with the strongest correlation between number and carbon dioxide. Except for sections of the text and figures referring to the diurnal pattern of emission factors, the result reported is based on the 04:00-10:00 a.m. restriction. Sensitivity of the result to this choice is discussed below.

The average number and volume emission factors as determined for Mexico City using the described method are $1.56 \times 10^{15}$ particles (from $11 \mathrm{~nm}$ to $494 \mathrm{~nm}$ ), and $9.48 \times 10^{11}$ cubic microns (from $11 \mathrm{~nm}$ to $494 \mathrm{~nm}$ ) per $\mathrm{kg}$ of carbon, respectively. The mode of the number emission factor is between 25 and $32 \mathrm{~nm}$, while the mode of the volume factor is
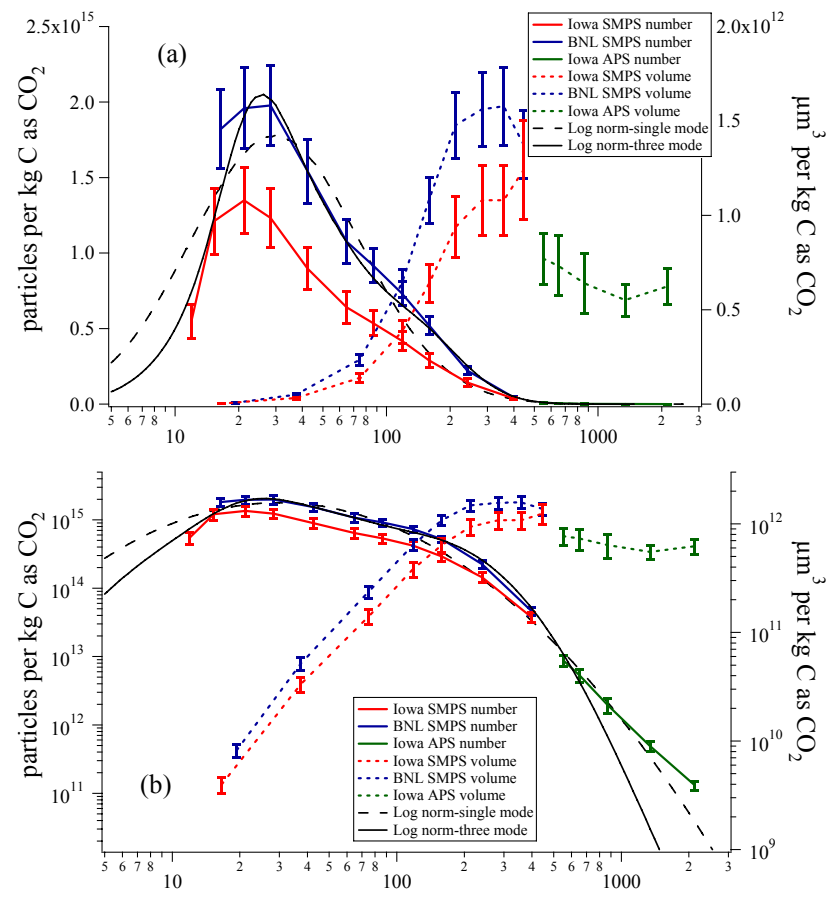

Fig. 7. Grand average number and volume emission factor distributions shown on both a log-linear (a) and a log-log (b) scale. These distributions represent the emission factors as determined using the data from 04:00 a.m. to 10:00 a.m. CST only, which was the time period with the strongest correlation between number and carbon dioxide. Error bars represent the $95 \%$ confidence interval based on variability in sampled values (see text for discussion of additional sources of uncertainty). The single mode and the three mode lognormal fits are also shown (see Table 4, rows 1 and 4, respectively, for parameters).

between 0.25 and 0.32 microns as shown in Fig. 7. The volume emission factor from 0.52 to 1.8 microns was $3.3 \times 10^{11}$ and $1.3 \times 10^{11}$ cubic microns per $\mathrm{cm}^{3}$ with the base and alternate APS data reductions, respectively.

An approximate estimate of the total uncertainty in the emission factor is done and includes contributions from both method and instrument uncertainty, and sampling error. A third source of error, representativeness error (e.g. how representative of the entire airshed is the recovered emission factor) is very difficult to quantify and is not considered in this work. However, its importance should not be minimized. The random uncertainty from the limited number of samples taken is the easiest to quantify, and we have taken advantage of the relatively large number of individual emission factors ( $\sim 600)$ to calculate a $95 \%$ confidence interval on the mean. This contributes approximately $\pm 10 \%$ to the grand average emission factor.

The potential for error in determination of number by the SMPS is $\sim 15 \%$ due primarily to uncertain flowrates, charging efficiency, and inlet efficiencies (Khlystov et al., 2004). The uncertainty in the Iowa SMPS is likely higher due to the 
Table 4. Parameters for lognormal modal fits of the emission factor.

\begin{tabular}{lccccl}
\hline Fit & Mode & $\mathrm{N} \mathrm{\#} \mathrm{(kg} \mathrm{C)}$ & $D_{\mathrm{p}}(\mathrm{nm})$ & log sigma & Notes \\
\hline $\begin{array}{l}\text { Single mode fit, 80\% weighted } \\
\text { to number distribution, 20\% }\end{array}$ & 1 & $1.78 \times 10^{15}$ & 29.7 & 0.40 & $\begin{array}{l}0.92 R^{2} \text { toward N; 0.80 } R^{2} \text { rel- } \\
\text { ative to V } \\
\text { weighted to volume distribution }\end{array}$ \\
\hline Three mode fit, 100\% weighted & 1 & $1.17 \times 10^{15}$ & 32.7 & 0.31 & $0.99 R^{2}$ toward N; 0.37 $R^{2}$ rel- \\
toward number distribution & 2 & $2.61 \times 10^{14}$ & 23.0 & 0.15 & ative to V \\
& 3 & $2.36 \times 10^{14}$ & 151 & 0.22 & \\
\hline Three mode fit, 100\% weighted & 1 & $2.32 \times 10^{15}$ & 32.7 & 0.36 & $0.63 R^{2}$ toward N; 0.97 $R^{2}$ rel- \\
toward volume distribution & 2 & $6.05 \times 10^{11}$ & 1339 & 0.60 & ative to V \\
& 3 & $2.48 \times 10^{13}$ & 229 & 0.15 & \\
\hline Three mode fit, 80\% weighted & 1 & $1.24 \times 10^{15}$ & 32.7 & 0.34 & $0.99 R^{2}$ toward N; $0.84 R^{2}$ rel- \\
to number distribution, 20\% & 2 & $2.57 \times 10^{14}$ & 23.4 & 0.15 & ative to V \\
weighted to volume distribution & 3 & $1.66 \times 10^{14}$ & 151 & 0.21 & \\
\hline
\end{tabular}

more severe inlet losses described in the experimental section. However, the BNL size distribution is used preferentially over the Iowa SMPS size distribution where available. The potential uncertainty due to the threshold selection in the calculation of the emission factor is thought to be within $20 \%$ (see below).

Combining these three sources of potential error, we find that the overall emission factor has a potential error of approximately 1.5. The uncertainty in the APS size range and in the volume emission factor are larger. Also, the uncertainty on emission factors for shorter periods (e.g. daily or sub-daily periods) is higher.

As stated in the experimental section, the $\mathrm{CO}_{2}$ measurement location and the number measurement location were separated by $150 \mathrm{~m}$, and true collocation would likely yield a significant improvement in the power of this technique, possibly improving the error characteristics and definitely allowing use of shorter averaging times, if desirable.

The emission factor with base case APS data reduction assumptions was fit to establish the corresponding lognormal mode parameters using constrained nonlinear optimization of an objective function that weighted the normalized number distribution of the emission factor by 0.8 and the normalized volume distribution of the emission factor by 0.2 . A constraint was put on the width of the modes such that log $\sigma$ was required to be 0.15 or higher; this avoids overly narrow peaks. A single mode fit achieved an $R^{2}$ of 0.92 with respect to the number distribution and an $R^{2}$ of 0.80 with respect to the volume distribution. This fit had parameters of $\mathrm{N} 1.78 \times 10^{15}$ particles per $\mathrm{kg} \mathrm{C}, D_{\mathrm{p}}$ of $30 \mathrm{~nm}$, and $\log \sigma$ of 0.40 (shown in Figs. 7 and 9). Significant improvement in the fit could be achieved but only by moving to 3 mode fits (also shown in Figs. 7 and 9). The parameters of these fits are shown in Table 4 . The single mode fit parameters were very insensitive to the relative weighting of number and volume.
Fitting based on volume only gave single mode (number size distribution) parameters of $D_{\mathrm{p}}$ of $30 \mathrm{~nm}$ and $\log \sigma$ of 0.38 .

Sensitivity of the emission factors to the $\mathrm{CO}_{2}$ threshold used in the peak identification process was performed. Higher emission factors resulted from the use of lower thresholds. $6 \mathrm{mg} \mathrm{CO}_{2} \mathrm{~m}^{-3}$ (the $72 \mathrm{nd}$ percentile of the $\mathrm{CO}_{2}$ peaks) was selected as the best threshold because it represented a good compromise between the tendency to have more emission factor values for small threshold values and the tendency of the variability in emission factors to increase substantially with small peaks. Using the threshold of $25 \mathrm{mg} \mathrm{m}^{-3}$, the fewest number of peaks were isolated for analysis. For example, the BNL instrument time series (restricted to 04:00-10:00 a.m.) yields 84 peaks during the 16 days analyzed when a threshold of $25 \mathrm{mg} \mathrm{m}^{-3}$ is used; this increases to $274,311,349$, and 393 peaks using the 8,6 , 4 , and $2 \mathrm{mg} \mathrm{m}^{-3}$ thresholds, respectively. The confidence interval of the mean number emission factor was smallest at $6 \mathrm{mg} \mathrm{m}^{-3}$ relative to those using small thresholds (more values to average, but with a higher variability), and higher thresholds (similar variability but fewer values informing the average). Jiang et al. (2005) considered changes to the threshold of $\pm 24 \%$ and showed that the $\mathrm{CO}$ emission factor only changed by $1-4 \%$ for this amount of change in the threshold. A similar perturbation to our threshold (e.g. $4.56,6$, and $7.44 \mathrm{mg} \mathrm{m}^{-3}$ ) shows a larger variability in the EF (17\% increase at 4.56 and $7 \%$ decrease at 7.44). Based on comparison of mean emission factors and their confidence intervals at thresholds of $4,6,8$ and $25 \mathrm{mg} \mathrm{m}^{-3}$, we estimate threshold selection as causing uncertainty of approximately $20 \%$. Using $25 \mathrm{mg} \mathrm{m}^{-3}$, the recovered emission factor decreased by $48 \%$ relative to the value at $6 \mathrm{mg} \mathrm{m}^{-3}$, while the confidence interval widened. It is unclear whether the observed decrease is due to differences in sources, differences in plume processing, or to correlated errors between $\Delta \mathrm{Num}$ 


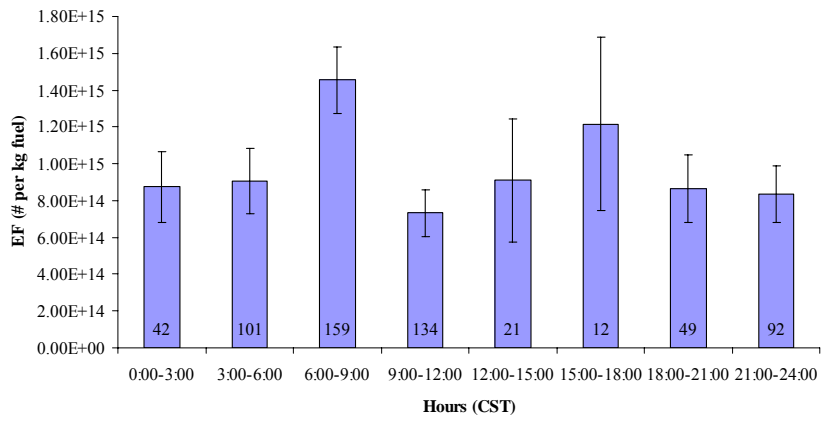

Fig. 8. Average emission factor versus time of day. The numbers on the graph represent the total number of $\mathrm{CO}_{2}$ peaks that went into the calculation of the emission factor for each $3 \mathrm{~h}$ period.

and $\Delta \mathrm{CO}_{2}$. However, the number of these plumes (with $\sim 25 \mathrm{mg} \mathrm{m}^{-3}$ above baseline $\mathrm{CO}_{2}$ ) is small and basing the overall emission factor on a larger sample is advisable. The spectral shape of the recovered size-resolved emission factor is insensitive to the threshold.

With the exception of Sect. 4.4, emission factors were calculated using only peaks from 04:00 a.m. to 10:00 a.m., since this is likely the most robust primary emission factor; this practice therefore excludes the influence of the afternoon hours which have small $\mathrm{CO}_{2}$ and number peaks (and thus with considerable uncertainty in their ratio). Using all hours instead of using the 04:00-10:00 a.m. period only caused a decrease in the grand average emission factor in all size ranges of the SMPS, with a magnitude of up to $20 \%$. In the APS size range, the effect of broadening the emission factors going into calculation of the grand average was to increase the emission factor in all size bins, by a magnitude of up to $20 \%$ for sizes between 0.5 and 1.8 microns, and a $32 \%$ decrease from 1.8 to 2.5 microns.

\subsection{Dependence of emission factors on time of day, day of study, and wind direction}

The average number emission factor as a function of time of day, and day of the month were examined in order to determine the impact that meteorological changes, biomass burning, or new particle formation may have on the overall emission factor. In doing this analysis, the aforementioned restriction to only peaks from 04:00-10:00 a.m. must of course be relaxed. And it should be noted that examination of diurnal patterns involves comparison of periods with varying uncertainty in emission factors.

A regional scale overview of the meteorological conditions during the MILAGRO campaign is provided by Fast et al. (2007). Based on the meteorology, the campaign was split into three regimes. The first regime occurred prior to 14 March and was characterized by dry, sunny conditions. The second regime began with a "Norte" or cold-surge event, which is characterized by northerly near-surface winds and
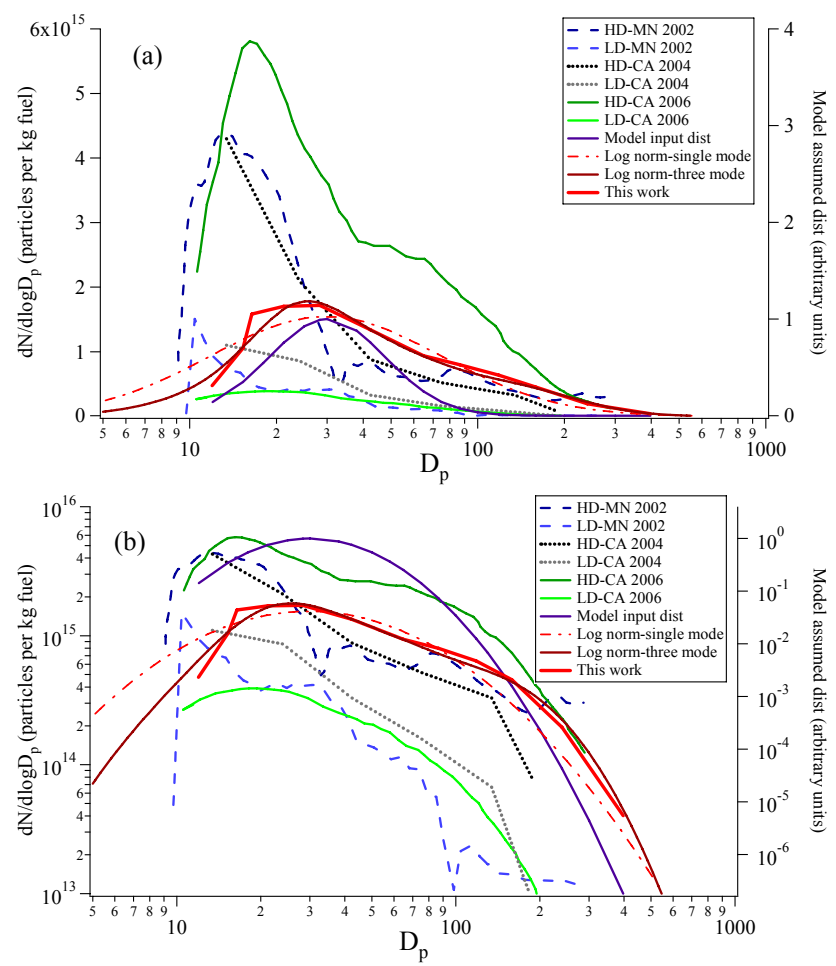

Fig. 9. Comparison of the measured emission factor distribution from Mexico City to experimentally determined, fleet averaged emission factors and a model assumed carbonaceous emission distribution. Panel (a) provides a comparison on a log-linear plot, and panel (b) shows the same comparison on a log-log plot. The model assumed distribution is listed in arbitrary units to allow for comparison of the distribution shape. See Table 4 for parameters of the single mode (row 1) and three mode (row 4) lognormal fits of the emission factor.

increased humidity on 14 March with a gradual drying of the atmosphere over the next few days. A second norte event, lasting only a few hours, passed through on 22 March bringing light rain. The third regime began with the most significant cold-surge on 23 March. Substantial precipitation was seen on both the 24th and 25th. The impact of biomass burning organic aerosol at T0 was characterized by Aiken et al. (2010). Two high fire periods are identified from 1115 March and 17.5-23.5 March; a low fire period coincident with increased precipitation is identified from 24-29 March. Details of the ultrafine particle formation and growth events observed at $\mathrm{T} 0$ are detailed in Table 3 .

The average emission factor for each day of the study was calculated. Day to day variation showed no statistical significance with the exception of 2 days (14 March and 24 March) which were slightly higher. This could not be explained by local fire activity or unique meteorological conditions. It is concluded that a time period longer than the 16 days analyzed here would be required to determine the correlation between airmass origin and emission factor with statistical 
significance. The retrieval method works by selecting peak areas above a baseline concentration, and slow increases in particle concentration (or $\mathrm{CO}_{2}$ ), such as those that might occur from changes in regional biomass burning activity may not influence the recovered emission factor. Days with new particle formation and growth activity have similar recovered emission factors as days without new particle formation and growth, and thus the method is not influenced by particle formation events.

The diurnal pattern of the emission factor is observed using 3-h averages as a function of time across all 16 days (Fig. 8). The number on each bar represents the total number of $\mathrm{CO}_{2}$ peaks that were identified and used to calculate an emission factor for each time period. As expected, the largest number of $\mathrm{CO}_{2}$ peaks was identified from 06:00 to 09:00, coincident with the morning rush hour traffic. Relatively very few peaks are detected from 12:00 to 18:00, during the time which the basin experiences ventilation and dilution.

An analysis of the wind directional dependence was performed, including plotting of pollution roses for number and volume, pollution roses for emission factors, and conditional probability functions for $\mathrm{CO}_{2}$ and emission factors. Normalizing for frequency of different wind directions, combined "number and $\mathrm{CO}_{2}$ " plumes were about 2 to 4 times more likely to originate from specific directions (the west, from the south, and from the northeast) than from other directions. These directions correspond to an industrial area (to the west), Vallejo Ave. (to the west), Eje 4 Ave. (to the south) and Eje Central Ave. (to the northeast). While $\mathrm{CO}_{2}$ had a directional signature, the emission factors themselves were much less dependent on direction. The $10 \mathrm{~min}$ periods with highest number to $\mathrm{CO}_{2}$ peak size ratios preferentially occurred under winds from the west. But more typical emission factors showed no directional dependence. Incidentally, the most common morning wind direction was from the west, possibly contributing to the directionality of the highest emission factors. The fact that emission factors are largely non-directional eliminates the possibility of recovering source-specific emission factors without additional source-specific markers. However, at the same time, it makes the recovered emission factor potentially more representative of a wide geographical area.

\subsection{Comparison to emission factors from literature}

The size-resolved number emission factors determined in this work are compared to those of three different experimental studies, and the result is shown in Fig. 9. Additionally, a representative size distribution used as input to a global aerosol model (Spracklen et al., 2010) is included in the figure. The single and three mode lognormal distributions are also shown.

The first study of interest was conducted in the Minneapolis metropolitan area by Kittelson and colleagues in summer of 2002 (Kittelson et al., 2006; Johnson et al., 2005).
On-road mobile measurements including the size distribution from 10-300 nm, $\mathrm{CO}$ and $\mathrm{CO}_{2}$, were collected under typical highway driving conditions. Then, the apportionment between SI and diesel vehicles was calculated using a differential traffic volume correlation method. $\mathrm{CO}_{2}$ and $\mathrm{CO}$ contributions were apportioned using the same method, and assuming these species represent the total carbon emitted, a conversion to fuel specific emission factors was made. The other two studies of interest were conducted in the Caldecott Tunnel in Northern California. The tunnel has two separate traffic bores; one which allows both heavy- and light-duty traffic, and the second which allows light-duty traffic only. In each of the tunnel studies, the emission factors are apportioned between diesel and gasoline vehicles by comparing the gasoline only bore to the mixed diesel and gasoline traffic bore. Geller et al. (2005) conducted measurements during the summer of 2004 which included the size distribution from 7-270 nm, $\mathrm{CO}$ and $\mathrm{CO}_{2}$. Light-duty emission factors were computed directly from the second bore, and were then used to apportion emissions in the mixed traffic bore. BanWeiss et al. (2010) conducted a similar study in the summer of 2006, which included measurements of the size distribution from 10 to $290 \mathrm{~nm}, \mathrm{CO}$, and $\mathrm{CO}_{2}$. Their apportionment calculations differed from Geller et al. in that they used $\mathrm{CO}_{2}$ as a tracer rather than $\mathrm{CO}$, citing that $\mathrm{CO}$ emissions have decreased more for diesel heavy-duty vehicles in recent years.

All three studies concluded that diesel trucks emitted more particles per kg of fuel burned than gasoline vehicles at all measured sizes. The Mexico City emission factor distribution falls in between the light duty and diesel apportioned emission factors as determined in Minnesota and California. Of the experimentally determined emission factors, the Mexico City emission factor has the largest peak diameter (in the 25 to $32 \mathrm{~nm}$ size bin) while all others were determined to be below $20 \mathrm{~nm}$. Perhaps this is because the aerosols in Mexico City are more aged in comparison, as supported by the larger than average growth rates observed in the ultrafine mode (Sect. 4.2). Alternatively, this could be due to differences in engine technology, or operation and maintenance procedures, or due to different representative fleet mixtures.

Tunnel studies such as the ones completed in the Caldecott tunnel, observe emissions after they have undergone "tailpipe to roadway" dilution (Zhang et al., 2004). The on-road measurements performed in Minnesota also observe emissions under "tailpipe to roadway" conditions, although under a wider variety of less controlled conditions. The measurements taken in Mexico City are more highly diluted, and are therefore thought to be ideal as inputs for 3-D models that do not account for near-source plume processes.

Currently, multiple 3-D chemical transport and aerosolclimate models represent the size distribution of carbonaceous emissions using lognormal modes with a number median radius of $30 \mathrm{~nm}$ (Spracklen et al., 2010; Stier et al., 2005). Then emission rates $\left(\mathrm{Tg} \mathrm{yr}^{-1}\right)$ compiled from emission inventories are distributed across the representative 
log-normal distribution functions (Spracklen et al., 2010; Dentener et al., 2006). For this reason, comparison on an absolute scale with the emission factor presented here is difficult. However, the shape of model input emission distribution is compared to the emission factor distribution recovered in this work in Fig. 9. While the mode of the two distributions is similar, the model assumed distribution is narrower and therefore may potentially underestimate the number of particles below $30 \mathrm{~nm}$ and above $40 \mathrm{~nm}$ relative to the mode.

The emission factor was also compared to published sizeresolved mass emission factors (from impactors applied to dynamometer tests of vehicles in the United States) where it was found that the field-based emission factor was larger at sizes greater than 1 micron (Robert et al., 2007).

\subsection{Application of emission factors to Mexico City plume}

The average emission factor of 425.4 particles $\mathrm{cm}^{-3}$ (mg $\left.\mathrm{CO}_{2} \mathrm{~m}^{-3}\right)^{-1}$ was used to estimate the number concentration of primary particles in the aged Mexico City plume based on $\mathrm{CO}_{2}$ measurements taken aboard the NASA DC8. The volume emission factor (through 2 microns) was $0.37 \mu \mathrm{m}^{3} \mathrm{~cm}^{-3}\left(\mathrm{mg} \mathrm{CO} \mathrm{m}^{-3}\right)^{-1}$ using the base case data processing assumptions. On a molar basis at the temperature, pressure, and water partial pressure of the aircraft sampling (296 K, 0.75 bar, 2.3 mbar $P_{\mathrm{H} 2 \mathrm{O}}$ ), the emission factors are 568 particles $\mathrm{cm}^{-3}\left(\mu \mathrm{mol} \mathrm{CO} \mathrm{mol}^{-1}\right)^{-1}$ and $0.49 \mu \mathrm{m}^{3} \mathrm{~cm}^{-3}$ $\left(\mu \mathrm{mol} \mathrm{CO} \mathrm{mol}^{-1}\right)^{-1}$. At 1.013 bar and $293 \mathrm{~K}$, the emission factors are somewhat higher (775 and 0.67, respectively). This estimated primary number concentration was compared to number concentrations measured on the aircraft. Because of extensive secondary particle formation and growth in the plume, agreement between the value based on the urban primary size-resolved emission factor and the in situ measurement is not expected; rather the difference may indicate the extent of plume processing. The data used for this analysis was taken on 11 March when the NASA DC-8 conducted a flight in order to sample the aged Mexico City plume as well as the near-source plume within the boundary layer. The aircraft made a pass over the city (19.45 lat. -99.07 lon. at $2530 \mathrm{~m}$ a.s.l., and the Mexico City plume is easily identified by the $\mathrm{CO}_{2}$ mixing ratio gradient where concentrations up to $400.5 \mu \mathrm{mol} \mathrm{mol}^{-1}$ are seen over the city, with a gradual decrease to background levels $\left(382 \mu \mathrm{mol} \mathrm{mol}^{-1}\right)$ traveling outward.

The number size distribution evolution at T0 during this day had particle volume peaking at 08:00 CST, a minimum in aerosol volume and aerosol scattering at noon, aerosol growth and mass increases during the early afternoon, and a significant drop in aerosol volume and aerosol scattering from an air mass change at $\sim 16: 30 \mathrm{CST}$. The DC-8 flew over Mexico City at high altitude $(\sim 9 \mathrm{~km}$ a.s.l.) and then flew north over T0, T1 and T2 at an altitude of $\sim 2.5 \mathrm{~km}$ a.s.1. or $<1 \mathrm{~km}$ above ground. In this analysis, we used five

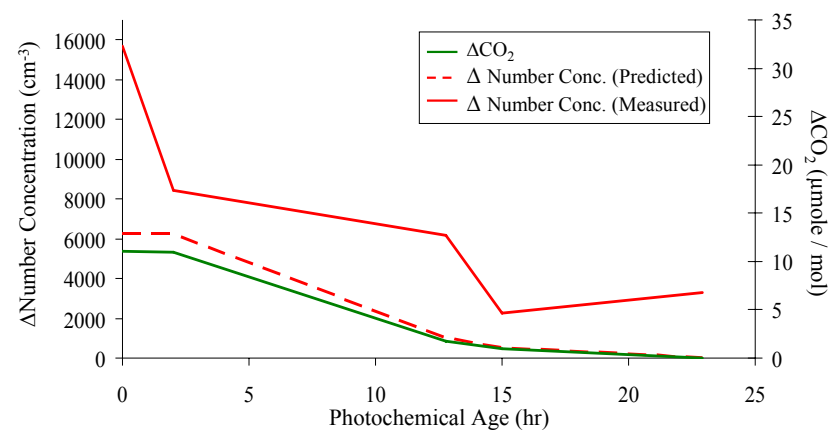

Fig. 10. Comparison of the measured particle number concentration (red), calculated baseline number concentration (green), and number concentration with background and anticipated primary number concentration from the emission factor of this work (dashed red). Measurements of $\mathrm{CO}_{2}$ and particle number concentration were obtained on 11 March 2006 aboard the NASA DC-8 flight which transected the Mexico City plume (14:15-14:30 CST). The emission factor used to predict the increase in particle number is 568 particles $\mathrm{cm}^{-3}\left(\mu \text { mole } \mathrm{CO}_{2} \mathrm{~mol}^{-1}\right)^{-1}$.

measurements of the particle size distribution beginning at 14:19 CST and covering a 10-min duration. The first measurement was obtained over the city $(0 \mathrm{~km})$, followed by measurements at $15.7,30.7,46.6$ and $61.8 \mathrm{~km}$ (where $\mathrm{CO}_{2}$ has decreased to within $0.5 \mu \mathrm{mol} \mathrm{mol}{ }^{-1}$ of the background concentration). Measurements of $\mathrm{CO}_{2}$ were obtained at 1-s resolution throughout the duration (Vay et al., 2009). The photochemical age at the time of each number concentration measurement was calculated using the measured ratio of toluene to benzene as described by Warneke et al. (2007).

For this comparison, the baseline $\mathrm{CO}_{2}$ and particle number concentrations aloft were determined using the same successive moving average subtraction method that was applied to the ground based measurements. During this period (consisting of five datapoints), the baseline of number concentration (through 1 micron) from the successive subtraction technique averages $3997 \mathrm{~cm}^{-3}$ and ranges from $3512 \mathrm{~cm}^{-3}$ to $4388 \mathrm{~cm}^{-3}$. The results from this analysis are provided in Fig. 10. The $\Delta \mathrm{CO}_{2}$ (green), which is the increase in $\mathrm{CO}_{2}$ mixing ratio above a baseline as measured by the aircraft, is plotted on the right axis versus photochemical age. The expected increase in particle number concentration above a baseline $(\Delta \mathrm{Num})$ from application of the primary emission factor is calculated by multiplying $\Delta \mathrm{CO}_{2}$ by the average emission factor and is represented by the dashed line. The actual measured $\Delta$ Num is represented by the solid red line.

As shown in Fig. 10, the measured increase in particle number concentration is significantly higher than the expected value from application of the emission factor determined at the ground. Our speculation is that there is a source of particles during plume aging that significantly increases particle number while leaving $\mathrm{CO}_{2}$ unchanged. New particle formation is a possible explanation for the elevated particle 

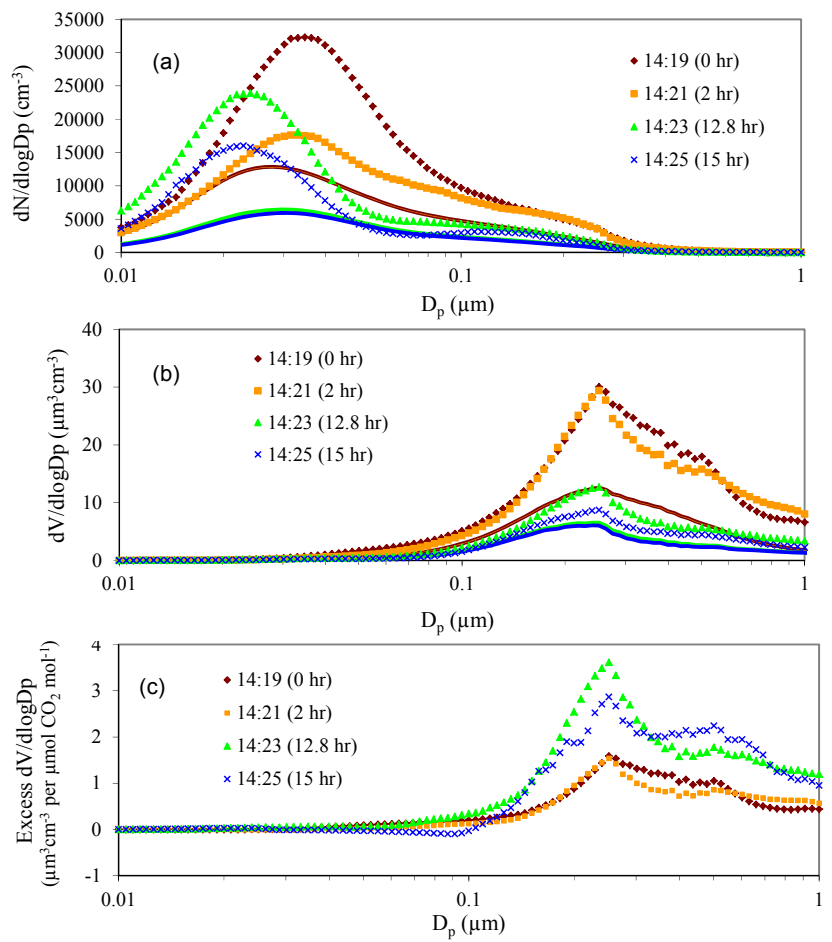

Fig. 11. Measured number and volume distributions in the DC-8 plume near Mexico City during the 11 March 2006 flight at average altitude of $342 \mathrm{~m}$ above ground at 14:20 local time. Panel (a) shows measured number size distributions (symbols) with calculated size distributions (lines) based on a regional background plus the primary emission factor (this work) times the $\mathrm{CO}_{2}$ increment above background. Panel (b) shows the same as (a) except number size distributions have been converted to volume distribution. Panel (c) shows the difference between measurement and background + primary, normalized to the $\mathrm{CO}_{2}$ increment in the plume. Photochemical ages, calculated using the benzene/toluene ratio relative to the ratio at 14:19, are shown by each distribution. Integrals of the volume distributions through 2 microns in (c) are $0.96 \pm 0.16,0.97 \pm 0.17,2.1 \pm 1.1$, and $1.8 \pm 2.1 \mu \mathrm{m}^{3} \mathrm{~cm}^{-3}$ per ppm. For reference, the primary emission factor (through 2 microns) is $0.49 \mu \mathrm{m}^{3} \mathrm{~cm}^{-3}$ per ppm.

number concentrations. The specific appearance of Fig. 10 is sensitive to the number baseline used to determine the increase relative to background. The increase in the baseline by $4300 \mathrm{~cm}^{-3}$ (on average) would bring the predicted (from primary emissions alone) $\Delta \mathrm{Num}$ and the measured $\Delta \mathrm{Num}$ into much closer agreement. The interpretation of this new background (which would be on average $8300 \mathrm{~cm}^{-3}$ ) is that it would require a particle source not associated with $\mathrm{CO}_{2}$ - and this could be from new particle formation, or from other non-combustion sources. For comparison, the average number baseline calculated for all samples below $3 \mathrm{~km}$ a.s.l. was $1800 \mathrm{~cm}^{-3}$ and the 90th percentile of the low altitude ( $<3 \mathrm{~km}$ a.s.1.) datapoints was $3600 \mathrm{~cm}^{-3}$, so $8300 \mathrm{~cm}^{-3}$ would be considered a high background value. The aver- age total number concentration at altitudes $<3 \mathrm{~km}$ a.s.l. is $3400 \mathrm{~cm}^{-3}$.

Figure 11 shows the analysis using the size resolved measurements (and the size resolved primary emission factor, represented by a single lognormal mode as discussed above) from the DC-8 rather than the total number. The four distributions (in symbols) shown on the graphs are labeled according to the time that the DC- 8 made the corresponding measurement as it transected the plume $(14: 19,14: 21,14: 23$, and 14:25). Rather than refer to each of the four traces by the time the measurement was made, it is informative to interpret the excess volume changes as a function of processing time in the atmosphere. The photochemical age (calculated using benzene:tolune) as calculated for measurements made at 14:19 CST was set to $0 \mathrm{~h}$ as a point of reference. Based on this information, the photochemical age of the measurement at $14: 21$ is $2 \mathrm{~h}, 12.8 \mathrm{~h}$ at $14: 23$, and $15 \mathrm{~h}$ at $14: 25$ (shown in parentheses in the legend).

Figure 11a shows the measured number distribution (symbols) and the number size distribution based only on extrapolation of the primary emission factor to the plume (lines). The prediction accounting for primary emissions only is equal to a background distribution plus the emission factor multiplied by the increment in $\mathrm{CO}_{2}$ above background $\left(\Delta \mathrm{CO}_{2}\right)$. The shape of the background distribution is calculated as the average of the measured number distributions from 14:16-14:27 CST, and the number is fixed at 3997 particles $\mathrm{cm}^{-3}$ (the background total number concentration calculated above). Both this shape and absolute number are uncertain. But even allowing for a higher background, the measured particle concentrations are well in excess of the "background plus primary" values at less than $40 \mathrm{~nm}$ for three of the four distributions. At sizes from 40 $100 \mathrm{~nm}$, the measured distribution is higher for three of the four distributions.

Figure $11 \mathrm{~b}$ and $\mathrm{c}$ focuses on the aerosol volume distribution. Figure $11 \mathrm{~b}$ graphs volume distributions based on measurements and on the primary emission factor of this work plus background. The background distribution function is calculated as the minimum of the volume distributions from 14:16-14:27 CST. The integral of this background volume distribution through 2 microns is $3.59 \mu \mathrm{m}^{3} \mathrm{~cm}^{-3}$. The integral of the volume distributions in Fig. 11b range from 5.6$18.8 \mu^{3} \mathrm{~cm}^{-3}$.

Figure $11 \mathrm{c}$ shows the volume distributions normalized to the $\mathrm{CO}_{2}$ increment above baseline. Consistent with the conclusions of Kleinman et al. (2009) the volume integral (and also the number concentration from $0.1-1$ microns, which is well correlated with volume) increase significantly with photochemical age; furthermore the change in shape (increase in volume without significant increase in mean size) is consistent with condensational growth rather than volume growth. While the number of measurements in this work is insufficient to show if this increase is linear with photochemical age as shown by Kleinman et al., the apparent secondary volume 
can be compared to the primary emitted volume from the emission factor of this work. In the 14:19 distribution, the volume above the calculated baseline (through 2 microns) is $1.38 \mu^{3} \mathrm{~cm}^{-3}$ per $\mu \mathrm{mol} \mathrm{CO} \mathrm{mol}^{-1}$, while the primary emission factor calculated at T0 (to within a factor 1.5) is 0.49 . Thus the primary emissions account for only $\sim 36 \%$ of the volume below 2 microns, even in this relatively fresh sample. In the later samples with VOC ages of 13-15 h, the fraction explained by the primary emissions drops to $\sim 20 \%$.

Using the $\mathrm{CO}$ to $\mathrm{CO}_{2}$ molar ratio of 0.045 determined in from aircraft measurements of the Mexico City plume (Vay et al., 2009) one can convert the $\mathrm{CO}_{2}$ based emission factors recovered in this work to CO-based emission factors. The emission factor of 775 particles $\mathrm{cm}^{-3}(\mu \mathrm{mol}$ $\left.\mathrm{CO}_{2} \mathrm{~mol}^{-1}\right)^{-1}$ used above converts to 17223 particles $\mathrm{cm}^{-3}$

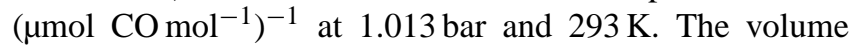
emission factor of $0.67 \mu \mathrm{m}^{3} \mathrm{~cm}^{-3}\left(\mu \mathrm{mol} \mathrm{CO} \mathrm{CO}_{2}^{-1}\right)^{-1}$ (through 2 microns) converts to $14.9 \mu \mathrm{m}^{3} \mathrm{~cm}^{-3}$ per $\mu \mathrm{mol} \mathrm{mol}^{-1}$ of CO. The volume emission factor through 0.44 microns (which matches the upper size limit of the DMA in Kleinman et al.) is then $11.9 \mu \mathrm{m}^{3} \mathrm{~cm}^{-3}$ per $\mu \mathrm{mol} \mathrm{mol}{ }^{-1}$ of CO. From Fig. 2 in Kleinman et al. (2009), the $y$ intercept of the DMA volume versus photochemical age is $\sim 11 \mu^{3} \mathrm{~cm}^{-3}$ per $\mu \mathrm{mol} \mathrm{mol}{ }^{-1}$ of CO.

This preliminary analysis of a small number of distributions from the DC-8, normalized to $\mathrm{CO}_{2}$ and referenced to a primary emission factor, is consistent with the more comprehensive analysis of aerosol aging on the G-1 aircraft. The primary emission factor of this work accounts for a fraction of the observed volume aloft close to Mexico City ranging from $\sim 20-36 \%$. The increase in aerosol volume relative to a marker of dilution $\left(\mathrm{CO}_{2}\right.$ increment above baseline) is similar to that documented by Kleinman et al. with a larger dataset from the G-1. The primary emission factor also cannot account for the observed aerosol number distribution aloft, particularly below $100 \mathrm{~nm}$. The mismatch is not systematic with photochemical age (as it appears to be for aerosol volume). The difference is likely due to secondary aerosol formation in the plume.

\section{Conclusions}

Measurements of the aerosol size distribution from $11 \mathrm{~nm}$ to 2.5 microns were made in Mexico City at the T0 site in March 2006, during the MILAGRO field campaign. Morning conditions included high particle mass concentrations, low mixing heights, and highly correlated particle number and $\mathrm{CO}_{2}$ concentrations. Mean concentrations of particle number and volume are: $20800 \mathrm{~cm}^{-3}$ and $18600 \mathrm{~cm}^{-3}$ (from the BNL and Iowa SMPS, respectively), and 15.4, 12.0, and $10.1 \mu \mathrm{m}^{3} \mathrm{~cm}^{-3}$ (from the BNL SMPS, Iowa SMPS, and APS respectively). Size ranges for these summary values run from $15-494 \mathrm{~nm}, 11-478 \mathrm{~nm}$, and $0.56-2.5 \mu \mathrm{m}$, respectively; for the APS size range of $0.56-2.5 \mu \mathrm{m}$, the summary value uses the base case data reduction assumption.

Ultrafine particle growth events, defined as a prominent growing mode at $10-15 \mathrm{~nm}$, were observed on 6 of 16 $(37.5 \%)$ days sampled at the T0 location. Events typically began between 10:30 and 13:00 local time. The growth rates of the ultrafine particles varied between 4.9 and $17.7 \mathrm{~nm} \mathrm{~h}^{-1}$.

Average size-resolved and total number- and volumebased emission factors for combustion sources impacting T0 have been determined using comparison of the areas of particle number and $\mathrm{CO}_{2}$ concentration peaks. The analysis is most sensitive to peaks smaller than $1 \mathrm{~h}$ in time duration, and is insensitive to slow changes in the $\mathrm{CO}_{2}$ and particle number baselines. The technique employed in the current work is somewhat sensitive to the $\mathrm{CO}_{2}$ peak threshold selection used, but is not sensitive to afternoon nucleation events, which happen during a time when $\mathrm{CO}_{2}$ does not peak above the threshold. The number emission and volume emission factors are $1.56 \times 10^{15}$ particles, and $9.48 \times 10^{11}$ cubic microns, per $\mathrm{kg}$ of carbon, respectively for the particle size distribution from $11 \mathrm{~nm}$ to $494 \mathrm{~nm}$. The uncertainty of the number emission factor is approximately plus or minus $50 \%$. In the APS size range, the uncertainty is larger and the mismatch between the SMPS and APS counts using the base case data processing assumptions indicate that further work is needed on APS inlet design, effective density, and data processing. The mode of the number emission factor was between 25 and $32 \mathrm{~nm}$, while the mode of the volume factor was between 0.25 and 0.32 microns.

Representing the emission factor as log normal modes yields parameters that may facilitate intercomparison of the emission factor and its use in modeling studies. For example, a single lognormal mode fit achieved an $R^{2}$ of 0.92 with respect to the number distribution and an $R^{2}$ of 0.80 with respect to the volume distribution. This fit had parameters of $\mathrm{N}$ equal to $1.78 \times 10^{15}$ particles per $\mathrm{kg} \mathrm{C}, D_{\mathrm{p}}$ of $30 \mathrm{~nm}$, and $\log \sigma$ of 0.40 (shown in Figs. 7 and 9). While $\mathrm{CO}_{2}$ and particle number exhibited preference for specific directions as determined by conditional probability of peaks versus wind direction, emission factors were largely insensitive to wind direction. While this limits potential to isolate specific sources, it does perhaps increase the ability to generalize the emission factor to wider parts of the Mexico City airshed.

The recovered emission factor resembles those used in some global modeling studies to represent carbonaceous aerosols. It also has a large number of common features with tunnel and chase studies aimed at isolating vehicle emission factors. The size-resolved emission factor from Mexico City is between several of the light-duty (lower emission factor) and heavy-duty (higher emission factor) emission factors from the United States. At sizes smaller than $30 \mathrm{~nm}$, the emission factor is lower than many vehicular emission factors, possibly due to the greater degree of scavenging of ultrafine particles between the point of emission and the point of sampling in our study versus the tunnel and chase studies. 
At sizes larger than $30 \mathrm{~nm}$, the emission factors from Mexico City are larger than several published vehicular emission factors.

Better collocation of the $\mathrm{CO}_{2}$, meteorology, and number size distribution measurement, and the use of faster instrumentation for the size distribution would increase the power of this technique to isolate shorter duration peaks and eliminate sources of uncertainty in the emission factor (although much of the variability is real and would remain).

Comparison of the size-resolved primary emission factor to the number distribution in the Mexico City plume aloft, as measured by the NASA DC-8 on 11 March 2006, was conducted. A plume with $\mathrm{CO}_{2}$ peaking at $11 \mu \mathrm{mol} \mathrm{mol}{ }^{-1}$ above background was isolated. The emission factor of this work explains (at $11 \mu \mathrm{mol} \mathrm{CO} \mathrm{mol}^{-1}$ enhancement) only about $6300 \mathrm{~cm}^{-3}$ of the number enhancement (which totaled $16000 \mathrm{~cm}^{-3}$ above background). This relative underprediction continued in subsequent samples with lower $\mathrm{CO}_{2}$ enhancements but was not correlated with photochemical age. The recovered emission factor was consistent with recent work showing that the ratio of total to primary aerosol in urban plumes can quickly grow to values of 2 to 5 .

Acknowledgements. This work was supported by funding from ATM07-48602, from NSF grant ATM05-11521, and US Department of Energy's Atmospheric Science Program (Office of Science, OBER) under contract DE-AC02-98CH10886. We would like to acknowledge Cameron McNaughton and Steven Howell who were responsible for maintenance and operation of the aerosol measurement system aboard the NASA DC-8. The authors would like to thank Nancy Marley (University of Arkansas-Little Rock) for their contributions of nephelometer and meteorological data.

Edited by: L. M. Russell

\section{References}

Adams, P. J. and Seinfeld, J. H.: Predicting global aerosol size distributions in general circulation models, J. Geophys. Res.Atmos., 107(D19), 4370, doi:10.1029/2001JD001010, 2002.

Aiken, A. C., Salcedo, D., Cubison, M. J., Huffman, J. A., DeCarlo, P. F., Ulbrich, I. M., Docherty, K. S., Sueper, D., Kimmel, J. R., Worsnop, D. R., Trimborn, A., Northway, M., Stone, E. A., Schauer, J. J., Volkamer, R. M., Fortner, E., de Foy, B., Wang, J., Laskin, A., Shutthanandan, V., Zheng, J., Zhang, R., Gaffney, J., Marley, N. A., Paredes-Miranda, G., Arnott, W. P., Molina, L. T., Sosa, G., and Jimenez, J. L.: Mexico City aerosol analysis during MILAGRO using high resolution aerosol mass spectrometry at the urban supersite (T0) - Part 1: Fine particle composition and organic source apportionment, Atmos. Chem. Phys., 9, 66336653, doi:10.5194/acp-9-6633-2009, 2009.

Aiken, A. C., de Foy, B., Wiedinmyer, C., DeCarlo, P. F., Ulbrich, I. M., Wehrli, M. N., Szidat, S., Prevot, A. S. H., Noda, J., Wacker, L., Volkamer, R., Fortner, E., Wang, J., Laskin, A., Shutthanandan, V., Zheng, J., Zhang, R., Paredes-Miranda, G., Arnott, W. P., Molina, L. T., Sosa, G., Querol, X., and Jimenez, J. L.: Mexico city aerosol analysis during MILAGRO using high resolution aerosol mass spectrometry at the urban supersite (T0) - Part 2: Analysis of the biomass burning contribution and the non-fossil carbon fraction, Atmos. Chem. Phys., 10, 5315-5341, doi:10.5194/acp-10-5315-2010, 2010.

Baker, A. K., Beyersdorf, A. J., Doezema, L. A., Katzenstein, A., Meinardi, S., Simpson, I. J., Blake, D. R., and Rowland, F. S.: Measurements of nonmethane hydrocarbons in 28 United States cities, Atmos. Environ., 42, 170-182, 2008.

Banta, R. M.: Late-Morning Jump in TKE in the Mixed Layer over a Mountain Basin, J. Atmos. Sci., 42, 407-411, 1985.

Ban-Weiss, G. A., Lunden, M. M., Kirchstetter, T. W., and Harley, R. A.: Size-resolved particle number and volume emission factors for on-road gasoline and diesel motor vehicles, J. Aerosol. Sci., 41, 5-12, 2010.

Bates, T. S., Anderson, T. L., Baynard, T., Bond, T., Boucher, O., Carmichael, G., Clarke, A., Erlick, C., Guo, H., Horowitz, L., Howell, S., Kulkarni, S., Maring, H., McComiskey, A., Middlebrook, A., Noone, K., O’Dowd, C. D., Ogren, J., Penner, J., Quinn, P. K., Ravishankara, A. R., Savoie, D. L., Schwartz, S. E., Shinozuka, Y., Tang, Y., Weber, R. J., and Wu, Y.: Aerosol direct radiative effects over the northwest Atlantic, northwest Pacific, and North Indian Oceans: estimates based on in-situ chemical and optical measurements and chemical transport modeling, Atmos. Chem. Phys., 6, 1657-1732, doi:10.5194/acp-6-1657-2006, 2006.

Baumgardner, D., Raga, G. B., Kok, G., Ogren, J., Rosas, I., Baez, A., and Novakov, T.: On the evolution of aerosol properties at a mountain site above Mexico City, J. Geophys. Res.-Atmos., 105, 22243-22253, 2000.

Chang, L. S., Schwartz, S. E., McGraw, R., and Lewis, E. R.: Sensitivity of aerosol properties to new particle formation mechanism and to primary emissions in a continental-scale chemical transport model, J. Geophys. Res.-Atmos., 114, D07203, doi:10.1029/2008JD011019, 2009.

Clarke, A. D.: Atmospheric Nuclei in the Pacific Midtroposphere - Their Nature, Concentration, and Evolution, J. Geophys. Res.Atmos., 98, 20633-20647, 1993.

Collins, D. R., Flagan, R. C., and Seinfeld, J. H.: Improved inversion of scanning DMA data, Aerosol Sci. Technol., 36, 1-9, 2002.

DeCarlo, P. F., Dunlea, E. J., Kimmel, J. R., Aiken, A. C., Sueper, D., Crounse, J., Wennberg, P. O., Emmons, L., Shinozuka, Y., Clarke, A., Zhou, J., Tomlinson, J., Collins, D. R., Knapp, D., Weinheimer, A. J., Montzka, D. D., Campos, T., and Jimenez, J. L.: Fast airborne aerosol size and chemistry measurements above Mexico City and Central Mexico during the MILAGRO campaign, Atmos. Chem. Phys., 8, 4027-4048, doi:10.5194/acp8-4027-2008, 2008.

de Foy, B., Varela, J. R., Molina, L. T., and Molina, M. J.: Rapid ventilation of the Mexico City basin and regional fate of the urban plume, Atmos. Chem. Phys., 6, 2321-2335, doi:10.5194/acp-6-2321-2006, 2006.

de Foy, B., Fast, J. D., Paech, S. J., Phillips, D., Walters, J. T., Coulter, R. L., Martin, T. J., Pekour, M. S., Shaw, W. J., Kastendeuch, P. P., Marley, N. A., Retama, A., and Molina, L. T.: Basinscale wind transport during the MILAGRO field campaign and comparison to climatology using cluster analysis, Atmos. Chem. Phys., 8, 1209-1224, doi:10.5194/acp-8-1209-2008, 2008.

de Foy, B., Zavala, M., Bei, N., and Molina, L. T.: Evaluation of 
WRF mesoscale simulations and particle trajectory analysis for the MILAGRO field campaign, Atmos. Chem. Phys., 9, 44194438, doi:10.5194/acp-9-4419-2009, 2009.

Delfino, R. J., Sioutas, C., and Malik, S.: Potential role of ultrafine particles in associations between airborne particle mass and cardiovascular health, Environ. Health Perspect., 113, 934-946, 2005.

Dentener, F., Kinne, S., Bond, T., Boucher, O., Cofala, J., Generoso, S., Ginoux, P., Gong, S., Hoelzemann, J. J., Ito, A., Marelli, L., Penner, J. E., Putaud, J.-P., Textor, C., Schulz, M., van der Werf, G. R., and Wilson, J.: Emissions of primary aerosol and precursor gases in the years 2000 and 1750 prescribed data-sets for AeroCom, Atmos. Chem. Phys., 6, 4321-4344, doi:10.5194/acp6-4321-2006, 2006.

Dunn, M. J., Jimenez, J. L., Baumgardner, D., Castro, T., McMurry, P. H., and Smith, J. N.: Measurements of Mexico City nanoparticle size distributions: Observations of new particle formation and growth, Geophys. Res. Lett., 31, L10102, doi:10.1029/2004GL019483, 2004.

Fast, J. D., de Foy, B., Acevedo Rosas, F., Caetano, E., Carmichael, G., Emmons, L., McKenna, D., Mena, M., Skamarock, W., Tie, X., Coulter, R. L., Barnard, J. C., Wiedinmyer, C., and Madronich, S.: A meteorological overview of the MILAGRO field campaigns, Atmos. Chem. Phys., 7, 2233-2257, doi:10.5194/acp-7-2233-2007, 2007.

Geller, M. D., Sardar, S. B., Phuleria, H., Fine, P. M., and Sioutas, C.: Measurements of particle number and mass concentrations and size distributions in a tunnel environment, Environ. Sci. Technol., 39, 8653-8663, 2005.

Geller, M. D., Biswas, S., and Sioutas, C.: Determination of Particle Effective Density in Urban Environments with a Differential Mobility Analyzer and Aerosol Particle Mass Analyzer, Aerosol Sci. Technol., 40, 709-723, 2006.

Iida, K., Stolzenburg, M. R., McMurry, P. H., and Smith, J. N.: Estimating nanoparticle growth rates from size-dependent charged fractions: Analysis of new particle formation events in Mexico City, J. Geophys. Res.-Atmos., 113, D05207, doi:10.1029/2007JD009260, 2008.

IPCC: Climate Change 2007: The Physical Science Basis: Contribution of Working Group I to the Fourth Assessment Report of the Intergovernmental Panel on Climate Change, Cambridge University Press, Cambridge, UK, 2007.

Jamriska, M. and Morawska, L.: A model for determination of motor vehicle emission factors from on-road measurements with a focus on submicrometer particles, Sci. Total Environ., 264, 241255,2001

Janhall, S. and Hallquist, M.: A Novel Method for Determination of Size-Resolved, Submicrometer Particle Traffic Emission Factors, Environ. Sci. Technol., 39, 7609-7615, 2005.

Jauregui, E.: Local wind and air pollution interaction in the Mexico Basin, Atmosfera, 1, 131-140, 1988.

Jiang, M., Marr, L. C., Dunlea, E. J., Herndon, S. C., Jayne, J. T., Kolb, C. E., Knighton, W. B., Rogers, T. M., Zavala, M., Molina, L. T., and Molina, M. J.: Vehicle fleet emissions of black carbon, polycyclic aromatic hydrocarbons, and other pollutants measured by a mobile laboratory in Mexico City, Atmos. Chem. Phys., 5, 3377-3387, doi:10.5194/acp-5-3377-2005, 2005.

Johnson, J. P., Kittelson, D. B., and Watts, W. F.: Source apportionment of diesel and spark ignition exhaust aerosol using on-road data from the Minneapolis metropolitan area, Atmos. Environ. 39, 2111-2121, 2005.

Kalafut-Pettibone, A.: Toward a Better Understanding of New Particle Formation, Ph.D. Thesis, Department of Chemical and Biochemical Engineering, University of Iowa, Iowa City, 2009.

Khlystov, A., Stanier, C., and Pandis, S. N.: An algorithm for combining electrical mobility and aerodynamic size distributions data when measuring ambient aerosol, Aerosol Sci. Technol., 38, 229-238, 2004.

Kirchstetter, T. W., Harley, R. A., Kreisberg, N. M., Stolzenburg, M. R., and Hering, S. V.: On-road measurment of fine particle and nitrogen oxide emissions from light- and heavy-duty motor vehicles, Atmos. Environ., 33, 2955-2968, 1999.

Kittelson, D. B., Watts, W. F., and Johnson, J. P.: Nanoparticle emissions on Minnesota highways, Atmos. Environ., 38, 9-19, 2004.

Kittelson, D. B., Watts, W. F., Johnson, J. P., Schauer, J. J., and Lawson, D. R.: On-road and laboratory evaluation of combustion aerosols - Part 2: Summary of spark ignition engine results, J. Aerosol. Sci., 37, 931-949, 2006.

Kleinman, L. I., Springston, S. R., Daum, P. H., Lee, Y.-N., Nunnermacker, L. J., Senum, G. I., Wang, J., Weinstein-Lloyd, J., Alexander, M. L., Hubbe, J., Ortega, J., Canagaratna, M. R., and Jayne, J.: The time evolution of aerosol composition over the Mexico City plateau, Atmos. Chem. Phys., 8, 1559-1575, doi:10.5194/acp-8-1559-2008, 2008.

Kleinman, L. I., Springston, S. R., Wang, J., Daum, P. H., Lee, Y.-N., Nunnermacker, L. J., Senum, G. I., Weinstein-Lloyd, J., Alexander, M. L., Hubbe, J., Ortega, J., Zaveri, R. A., Canagaratna, M. R., and Jayne, J.: The time evolution of aerosol size distribution over the Mexico City plateau, Atmos. Chem. Phys., 9, 4261-4278, doi:10.5194/acp-9-4261-2009, 2009.

Kolb, C. E., Herndon, S. C., McManus, B., Shorter, J. H., Zahniser, M. S., Nelson, D. D., Jayne, J. T., Canagaratna, M. R., and Worsnop, D. R.: Mobile laboratory with rapid response instruments for real-time measurements of urban and regional trace gas and particulate distributions and emission source characteristics, Environ. Sci. Technol., 38, 5694-5703, 2004.

Kristensson, A., Johansson, C., Westerholm, R., Swietlicki, E., Gidhagen, L., Wideqvist, U., and Vesely, V.: Real-world traffic emission factors of gases and particles measured in a road tunnel in Stockholm, Sweden, Atmos. Environ., 38, 657-673, 2004.

Kulmala, M. and Kerminen, V. M.: On the formation and growth of atmospheric nanoparticles, Atmos. Res., 90, 132-150, 2008.

Kulmala, M., Vehkamaki, H., Petaja, T., Dal Maso, M., Lauri, A., Kerminen, V. M., Birmili, W., and McMurry, P. H.: Formation and growth rates of ultrafine atmospheric particles: a review of observations, J. Aerosol. Sci., 35, 143-176, 2004.

Leinert, S. and Wiedensohler, A.: APS Counting Efficiency Calibration for Submicrometer Particles, J. Aerosol. Sci., 31, Suppl. 1, S404-S405, 2000.

Lohmann, U. and Feichter, J.: Global indirect aerosol effects: a review, Atmos. Chem. Phys., 5, 715-737, doi:10.5194/acp-5-7152005, 2005.

Marley, N. A., Gaffney, J. S., Castro, T., Salcido, A., and Frederick, J.: Measurements of aerosol absorption and scattering in the Mexico City Metropolitan Area during the MILAGRO field campaign: a comparison of results from the T0 and T1 sites, Atmos. Chem. Phys., 9, 189-206, doi:10.5194/acp-9-189-2009, 2009.

McGaughey, G. R., Desai, N. R., Allen, D. T., Seila, R. L., Lon- 
neman, W. A., Fraser, M. P., Harley, R. A., Pollak, A. K., Ivy, J. M., and Price, J. H.: Analysis of motor vehicle emissions in a Houston tunnel during the Texas Air Quality Study 2000, Atmos. Environ., 38, 3363-3372, 2004.

Mills, N. L., Donaldson, K., Hadoke, P. W., Boon, N. A., MacNee, W., Cassee, F. R., Sandstrom, T., Blomberg, A., and Newby, D. E.: Adverse cardiovascular effects of air pollution, Nat. Clin. Pract. Cardiovasc. Med., 6, 36-44, 2009.

Molina, L. T., Kolb, C. E., de Foy, B., Lamb, B. K., Brune, W. H., Jimenez, J. L., Ramos-Villegas, R., Sarmiento, J., ParamoFigueroa, V. H., Cardenas, B., Gutierrez-Avedoy, V., and Molina, M. J.: Air quality in North America's most populous city overview of the MCMA-2003 campaign, Atmos. Chem. Phys., 7, 2447-2473, doi:10.5194/acp-7-2447-2007, 2007.

Molina, L. T., Madronich, S., Gaffney, J. S., and Singh, H. B.: Overview of MILAGRO/INTEX-B Campaign, IGAC Newsletter, 2-15, 2008.

Ning, Z., Polidori, A., Schauer, J. J., and Sioutas, C.: Emission factors of PM species based on freeway measurements and comparison with tunnel and dynamometer studies, Atmos. Environ., 42, 3099-3114, 2008.

Oberdorster, G., Oberdorster, E., and Oberdorster, J.: Nanotoxicology: An emerging discipline evolving from studies of ultrafine particles, Environ. Health Perspect., 113, 823-839, 2005.

Osornio-Vargas, A. R., Bonner, J. C., Alfaro-Moreno, E., Martinez, L., Garcia-Cuellar, C., Rosales, S. P. D., Miranda, J., and Rosas, I.: Proinflammatory and cytotoxic effects of Mexico City air pollution particulate matter in vitro are dependent on particle size and composition, Environ. Health Perspect., 111, 1289-1293, 2003.

Pierce, J. R. and Adams, P. J.: Efficiency of cloud condensation nuclei formation from ultrafine particles, Atmos. Chem. Phys., 7, 1367-1379, doi:10.5194/acp-7-1367-2007, 2007.

Pierce, J. R. and Adams, P. J.: Uncertainty in global CCN concentrations from uncertain aerosol nucleation and primary emission rates, Atmos. Chem. Phys., 9, 1339-1356, doi:10.5194/acp-91339-2009, 2009.

Querol, X., Pey, J., Minguilln, M. C., Prez, N., Alastuey, A., Viana, M., Moreno, T., Bernabé, R. M., Blanco, S., Cárdenas, B., Vega, E., Sosa, G., Escalona, S., Ruiz, H., and Artñano, B.: PM speciation and sources in Mexico during the MILAGRO-2006 Campaign, Atmos. Chem. Phys., 8, 111-128, doi:10.5194/acp-8-1112008, 2008.

Ristovski, Z. D., Morawska, L., Bofinger, N. D., and Hitchins, J.: Submicrometer and supermicrometer particulate emission from spark ignition vehicles, Environ. Sci. Technol., 32, 3845-3852, 1998.

Robert, M. A., Jakober, C. A., VanBergen, S., and Kleeman, M. J.: Size and Composition Distribution of Particulate Matter 1. Light-duty Gasoline Vehicles, J. Air Waste Manage. Assoc., 57, 1414-1428, 2007.

Roberts, G. C., Day, D. A., Russell, L. M., Dunlea, E. J., Jimenez, J. L., Tomlinson, J. M., Collins, D. R., Shinozuka, Y., and Clarke, A. D.: Characterization of particle cloud droplet activity and composition in the free troposphere and the boundary layer during INTEX-B, Atmos. Chem. Phys., 10, 6627-6644, doi:10.5194/acp-10-6627-2010, 2010.

Salcedo, D., Onasch, T. B., Dzepina, K., Canagaratna, M. R., Zhang, Q., Huffman, J. A., DeCarlo, P. F., Jayne, J. T., Mor- timer, P., Worsnop, D. R., Kolb, C. E., Johnson, K. S., Zuberi, B., Marr, L. C., Volkamer, R., Molina, L. T., Molina, M. J., Cardenas, B., Bernabé, R. M., Márquez, C., Gaffney, J. S., Marley, N. A., Laskin, A., Shutthanandan, V., Xie, Y., Brune, W., Lesher, R., Shirley, T., and Jimenez, J. L.: Characterization of ambient aerosols in Mexico City during the MCMA-2003 campaign with Aerosol Mass Spectrometry: results from the CENICA Supersite, Atmos. Chem. Phys., 6, 925-946, doi:10.5194/acp-6-9252006, 2006.

Smith, J. N., Dunn, M. J., VanReken, T. M., Iida, K., Stolzenburg, M. R., McMurry, P. H., and Huey, L. G.: Chemical composition of atmospheric nanoparticles formed from nucleation in Tecamac, Mexico: Evidence for an important role for organic species in nanoparticle growth, Geophys. Res. Lett., 35, L04808, doi:10.1029/2007GL032523, 2008.

Spracklen, D. V., Carslaw, K. S., Merikanto, J., Mann, G. W., Reddington, C. L., Pickering, S., Ogren, J. A., Andrews, E., Baltensperger, U., Weingartner, E., Boy, M., Kulmala, M., Laakso, L., Lihavainen, H., Kivekäs, N., Komppula, M., Mihalopoulos, N., Kouvarakis, G., Jennings, S. G., O’Dowd, C., Birmili, W., Wiedensohler, A., Weller, R., Gras, J., Laj, P., Sellegri, K., Bonn, B., Krejci, R., Laaksonen, A., Hamed, A., Minikin, A., Harrison, R. M., Talbot, R., and Sun, J.: Explaining global surface aerosol number concentrations in terms of primary emissions and particle formation, Atmos. Chem. Phys., 10, 4775-4793, doi:10.5194/acp-10-4775-2010, 2010.

Stanier, C. O., Khlystov, A. Y., Chan, W. R., Mandiro, M., and Pandis, S. N.: A method for the in situ measurement of fine aerosol water content of ambient aerosols: The dry-ambient aerosol size spectrometer (DAASS), Aerosol Sci. Technol., 38, 215-228, 2004.

Stier, P., Feichter, J., Kinne, S., Kloster, S., Vignati, E., Wilson, J., Ganzeveld, L., Tegen, I., Werner, M., Balkanski, Y., Schulz, M., Boucher, O., Minikin, A., and Petzold, A.: The aerosolclimate model ECHAM5-HAM, Atmos. Chem. Phys., 5, 11251156, doi:10.5194/acp-5-1125-2005, 2005.

Vay, S. A., Woo, J. H., Anderson, B. E., Thornhill, K. L., Blake, D. R., Westberg, D. J., Kiley, C. M., Avery, M. A., Sachse, G. W., Streets, D. G., Tsutsumi, Y., and Nolf, S. R.: Influence of regional-scale anthropogenic emissions on $\mathrm{CO} 2$ distributions over the western North Pacific, J. Geophys. Res.-Atmos., 108, 8801, doi:10.1029/2002JD003094, 2003.

Vay, S. A., Tyler, S. C., Choi, Y., Blake, D. R., Blake, N. J., Sachse, G. W., Diskin, G. S., and Singh, H. B.: Sources and transport of $\Delta^{14} \mathrm{C}$ in $\mathrm{CO}_{2}$ within the Mexico City Basin and vicinity, Atmos. Chem. Phys., 9, 4973-4985, doi:10.5194/acp-9-4973-2009, 2009.

Velasco, E., Pressley, S., Grivicke, R., Allwine, E., Coons, T., Foster, W., Jobson, B. T., Westberg, H., Ramos, R., Hernández, F., Molina, L. T., and Lamb, B.: Eddy covariance flux measurements of pollutant gases in urban Mexico City, Atmos. Chem. Phys., 9, 7325-7342, doi:10.5194/acp-9-7325-2009, 2009.

Volkamer, R., Jimenez, J. L., San Martini, F., Dzepina, K., Zhang, Q., Salcedo, D., Molina, L. T., Worsnop, D. R., and Molina, M. J.: Secondary organic aerosol formation from anthropogenic air pollution: Rapid and higher than expected, Geophys. Res. Lett., 33, L17811, doi:10.1029/2006GL026899, 2006.

Wang, J., Flagan, R. C., and Seinfeld, J. H.: Diffusional losses in particle sampling systems containing bends and elbows, J. 
Aerosol. Sci., 33, 843-857, 2002.

Wang, J., Flagan, R. C., and Seinfeld, J. H.: A differential mobility analyzer (DMA) system for submicron aerosol measurements at ambient relative humidity, Aerosol Sci. Technol., 37, 46-52, 2003.

Wang, M. and Penner, J. E.: Aerosol indirect forcing in a global model with particle nucleation, Atmos. Chem. Phys., 9, 239-260, doi:10.5194/acp-9-239-2009, 2009.

Warneke, C., McKeen, S. A., de Gouw, J. A., Goldan, P. D., Kuster, W. C., Holloway, J. S., Williams, E. J., Lerner, B. M., Parrish, D. D., Trainer, M., Fehsenfeld, F. C., Kato, S., Atlas, E. L., Baker, A., and Blake, D. R.: Determination of urban volatile organic compound emission ratios and comparison with an emissions database, J. Geophys. Res.-Atmos., 112, D10S47, doi:10.1029/2006JD007930, 2007.

Watson, J. G. and Chow, J. C.: Estimating middle-, neighborhood-, and urban-scale contributions to elemental carbon in Mexico City with a rapid response aethalometer, J. Air Waste Manage. Assoc., 51, 1522-1528, 2001.

Weber, R. J., Marti, J. J., McMurry, P. H., Eisele, F. L., Tanner, D. J., and Jefferson, A.: Measurements of new particle formation and ultrafine particle growth rates at a clean continental site, J. Geophys. Res.-Atmos., 102, 4375-4385, 1997.
Westerdahl, D., Wang, X., Pan, X. C., and Zhang, K. M.: Characterization of on-road vehicle emission factors and microenvironmental air quality in Beijing, China, Atmos. Environ., 43, 697705, 2009.

Yu, F. Q., Luo, G., Bates, T. S., Anderson, B., Clarke, A., Kapustin, V., Yantosca, R. M., Wang, Y. X., and Wu, S. L.: Spatial distributions of particle number concentrations in the global troposphere: Simulations, observations, and implications for nucleation mechanisms, J. Geophys. Res.-Atmos., 115, D17205, doi:10.1029/2009JD013473, 2010.

Zavala, M., Herndon, S. C., Wood, E. C., Jayne, J. T., Nelson, D. D., Trimborn, A. M., Dunlea, E., Knighton, W. B., Mendoza, A., Allen, D. T., Kolb, C. E., Molina, M. J., and Molina, L. T.: Comparison of emissions from on-road sources using a mobile laboratory under various driving and operational sampling modes, Atmos. Chem. Phys., 9, 1-14, doi:10.5194/acp-9-1-2009, 2009.

Zhang, J. and Morawska, L.: Combustion sources of particles: 2. Emission factors and measurement methods, Chemosphere, 49, 1059-1074, 2002.

Zhang, K. M., Wexler, A. S., Zhu, Y. F., Hinds, W. C., and Sioutas, C.: Evolution of particle number distribution near roadways. Part II: the 'road-to-ambient' process, Atmos. Environ., 38, 6655$6665,2004$. 